\title{
Absorptive capacity, strategic flexibility, and business model innovation: Empirical evidence from Italian SMEs
}

\begin{abstract}
Recognizing that business model innovation (BMI) is a constant source of value creation in the digital economy, we examine the nexus between absorptive capacity and strategic flexibility, and their effects on BMI. We argue that to increase strategic flexibility and innovate their business model, firms need to develop their potential absorptive capacity (acquisition and assimilation of knowledge) as well as their realized absorptive capacity (transformation and exploitation of knowledge). While potential absorptive capacity drives both BMI and strategic flexibility, realized absorptive capacity increases a firm's strategic flexibility. Our analysis of 282 Italian small- and medium-sized firms also shows a relationship between realized absorptive capacity and BMI, but only under conditions of environmental uncertainty.
\end{abstract}

Keywords: Business model innovation, Absorptive capacity, Strategic flexibility, SMEs 


\section{Introduction}

Digital challenges have pushed many firms to make their businesses strategically flexible and more innovative (Nylén \& Holmström, 2015). Firms aspire to business model innovation (BMI), mainly defined as the change in the organizational value creation architecture (Foss \& Saebi, 2018). A large-scale CEO survey of IBM Global Business Services (2006) reports that BMI is a constant source of value creation for firms around the globe. Similarly, leading management and innovation consulting firms emphasize that BMI can deliver more sustained competitive advantage in times of continuous change (e.g. Vermuelen, 2018). Therefore, top management teams search and deploy organizational resources and capabilities in the attempt to achieve BMI (Spieth, Schneckenberg, \& Ricart, 2014; Teece, 2010).

The concept of BMI has also started to gain prominence in the academic community, particularly in management research (Clauss, Abebe, Tangpong, \& Hock, 2019; Foss \& Saebi, 2018; Schneider \& Spieth, 2013; Spieth et al., 2014). Several attempts have been made to understand BMI as a process (e.g. Frankerberger, Weiblen, Csik, \& Gassmann, 2013) and its relationship to strategy (e.g. Spieth, Schneckenberg, \& Matzler, 2016), to develop BMI typologies (e.g. Johnson, Christensen, \& Kagermann, 2008), and disentangle BMI performance outcomes (e.g. Zott \& Amit, 2007, 2008). However, a first systematic literature review covering more than two decades of BMI research emphasizes that existing studies have largely overlooked the question of internal BMI drivers (Foss \& Saebi, 2017). Specifically, there is limited research on whether and how the firm's absorptive capacity and strategic flexibility influence the adoption of BMI. Therefore, in this study we aim to examine the nexus between absorptive capacity and strategic flexibility, and their effects on BMI using unique survey data from 282 Italian small- and mediumsized firms (SMEs).

Absorptive capacity is an important construct that influences strategic flexibility and various 
forms of innovation. Absorptive capacity, as the firm's ability to recognize, assimilate, and apply valuable, new, and external information, is critical for its innovation capabilities (Cohen \& Levinthal, 1990). Substantial empirical research shows that a firm's absorptive capacity influences innovation and performance (Ali, Seny Kan, \& Sarstedt, 2016; Cepeda-Carrion, Cegarra-Navarro, \& Jimenez-Jimenez, 2012; Kostopoulos, Papalexandris, Papachroni, \& Ioannou, 2011). Absorptive capacity is an important precondition for the renewal of a firm's knowledge base (Zahra \& George, 2002). This in turn leads to a higher rate of innovation and greater flexibility in the reconfiguration of the resource base. Innovation and flexibility are both drivers of competitive advantage (Zahra \& George, 2002). In this paper, we argue that to increase strategic flexibility and innovate their business model, firms need to develop their potential absorptive capacity (acquisition and assimilation of knowledge) as well as their realized absorptive capacity (transformation and exploitation of knowledge).

Strategic flexibility emphasizes the flexible use of resources and reconfiguration of processes, reflecting a type of dynamic capability (Eisenhardt \& Martin, 2000). It is considered a key determinant of competitive advantage in turbulent markets (Hitt, Keats, \& DeMarie, 1998). Strategic flexibility positively influences new product development (Kandemir \& Acur, 2012), explorative innovation (Zhou \& Wu, 2010), and innovation capabilities (Fan, Wu, \& Wu, 2013). Based on this literature, we will argue that strategic flexibility is an important driver of BMI.

Our investigation highlights the importance of absorptive capacity, and offers important theoretical and practical implications. Our first theoretical contribution is to the emerging BMI literature (Foss \& Saebi, 2017; Schneider \& Spieth, 2013; Spieth et al., 2014). While this literature stream provides limited empirical insights on the internal drivers of BMI (Bock, Opsahl, George, \& Gann, 2012; Khanagha, Volberda, \& Oshri, 2014; Schneider \& Spieth, 2014), such as strategic flexibility (Clauss et al., 2019), absorptive capacity in firms' BMI remains uninvestigated. We 
consider absorptive capacity as a key antecedent of strategic flexibility and innovation. To our best knowledge, the present study is the first to do so. We respond to the call of Foss and Saebi (2017) for a better understanding of the internal antecedents of BMI, and provide unique empirical evidence using primary data. Furthermore, we also provide insights to research investigating the relationship between strategic flexibility and BMI (e.g., Clauss et al., 2019; Doz \& Kosonen, 2008), suggesting that contextual issues might blur this relationship.

Our second theoretical contribution is to the strategic flexibility literature (Brozovic, 2018; Hitt et al., 1998; Sanchez, 1995; Zhou \& Wu, 2010) analyzing the relationship between strategic flexibility and modularity (Sanchez \& Mahoney, 1996; Worren, Moore, \& Cardona, 2002) by identifying the role of potential and realized absorptive capacity in developing strategic flexibility. Specifically, we show that potential absorptive capacity has direct and indirect effects through realized absorptive capacity on strategic flexibility, thereby providing a more fine-grained understanding of the organizational determinants of strategic flexibility in the context of SMEs.

Our third theoretical contribution is to the absorptive capacity literature. While research has shown that absorptive capacity influences a firm's innovation decisions (e.g. Boyd \& Hollensen, 2012), it has not yet examined how absorptive capacity shapes BMI and its role in the nexus between strategic flexibility and BMI. Our findings reveal that not all the dimensions of absorptive capacity have the same role, providing a more fine-grained understanding of the individual role of potential and realized absorptive capacity for strategic flexibility and BMI. These findings also have important managerial implications for SMEs owners and managers.

\section{Theoretical background and hypotheses development}

Environmental dynamism and turbulence affect most industries today, prompting BMI through adaptation (e.g., Clauss et al., 2019). BMI refers to "a new-to-the-firm change in at least one out 
of three business model dimensions: (a) a firm's value offering, (b) a firm's value creation architecture, and (c) a firm's revenue model logic" (Spieth \& Schneider, 2016, p. 690). While value offering captures what a firm offers its customers, value architecture describes how this offering is realized within the firm and in its network with other organizations. Finally, the revenue model shows how firms capture value for themselves through revenue logics and cost structures (Clauss, 2017; Spieth \& Schneider, 2016). For firms operating in extremely dynamic environments, continuously acquiring, assimilating, transforming, and exploiting new knowledge, and doing so flexibly, is critical to success. It allows firms to develop absorptive capacity to sustain their competitive advantage (Zahra \& George, 2002). Absorptive capacity is a firm's "ability to recognize the value of new information, assimilate it, and apply it to commercial ends" (Cohen \& Levinthal, 1990, p. 128). This ability is a function of prior related knowledge and encompasses potential and realized aspects. Potential absorptive capacity refers to attempts to identify and acquire new external knowledge, and assimilate knowledge obtained from external sources (Zahra \& George, 2002). Realized absorptive capacity includes developing novel insights and results from consolidating existing and newly acquired knowledge and transforming knowledge into business operations (Zahra \& George, 2002). These capabilities sustain competitive advantage by increasing a firm's strategic flexibility while shaping a firm's innovation activities, such as BMI (Clauss et al., 2019; Zahra \& George, 2002). Strategic flexibility is defined as "the organizational ability to manage economic and political risks by promptly responding in a proactive or reactive manner to market threats and opportunities" (Grewal \& Tansuhaj, 2001, p. 72), and is also deemed to drive BMI (Clauss et al., 2019).

In the next sections, we develop a set of hypotheses outlining the theoretical links between these constructs, specifically: 1) the baseline nexus between absorptive capacity and strategic flexibility; 2) the role of absorptive capacity in BMI; 3) the way in which absorptive capacity translates into 
BMI via strategic flexibility.

\subsection{Absorptive capacity and strategic flexibility}

As outlined above, in increasingly dynamic environments, managing and transforming a company's knowledge stock is key. Companies do so by developing absorptive capacity to sustain their competitive advantage by increasing the firm's strategic flexibility and level of innovativeness. According to Zahra and George (2002), absorptive capacity manifests through the concurrent presence of four core elements, two of which refer to potential absorptive capacity (knowledge acquisition and knowledge assimilation), and two to realized absorptive capacity (knowledge transformation and knowledge exploitation). Potential absorptive capacity can be particularly strong in firms with organizational mechanisms such as job rotation, cross-functional interfaces, and participation in decision-making (Jansen, Van Den Bosch, \& Volberda, 2005). Instead, organizational mechanisms associated with socializing capabilities, such as connectedness and socialization tactics (Jansen et al., 2005), foster realized absorptive capacity. The two absorptive capacity dimensions have distinct but complementing roles. While potential absorptive capacity enables companies to discover competitive options for a sustainable development, it does

not guarantee that these options are pursued successfully. Zahra and George (2002, p. 191) highlight that "firms can acquire and assimilate knowledge but might not have the capability to transform and exploit the knowledge for profit generation." Hence, the acquisition and assimilation of new knowledge (potential absorptive capacity) are prerequisites of exploiting realized absorptive capacity (Jansen et al., 2005; Zahra \& George, 2002). These arguments lead us to our first hypothesis:

H1: Potential absorptive capacity is positively associated with realized absorptive capacity. 
Innovative firms need to develop a set of organizational capabilities offering a portfolio of possible scenarios involving "the development of critical resource identification, acquisition, deployment capabilities, and option identification capabilities" (Johnson, Lee, Saini, \& Grohmann, 2003, p. 87). These capabilities help firms meet ever-increasing customer requests and adjust their operations according to the latest market trends and demands (Davies \& Brady, 2000; Dosi, Nelson, \& Winter, 2001; Eisenhardt \& Martin, 2000). In addition, they help firms in times of severe economic shocks (Makkonen, Pohjola, Olkkonen, \& Koponen, 2014).

Potential absorptive capacity as the firm's ability to identify changes in the environment facilitates the deployment of necessary capabilities, contributing to renewing the knowledge base and skills, and the more flexible use of resources and capabilities. In fact, several scholars suggest that potential absorptive capacity can increase competitive advantage through flexibility (Jansen et al., 2005; Volberda, Foss, \& Lyles, 2010). The continuous acquisition and assimilation of external knowledge derived from the firm's potential absorptive capacity is an important requirement for flexibility. Only firms that have well-developed capabilities to acquire and assimilate knowledge will be able to identify trends and opportunities, and thus flexibly reconfigure their resource base (Zahra \& George, 2002). In other words, only firms with a strong ability to acquire and assimilate external knowledge are likely to have a high level of strategic flexibility allowing them to promptly and adequately react to business risks and opportunities. Therefore:

H2: Potential absorptive capacity is positively associated with strategic flexibility.

\subsection{Absorptive capacity and business model innovation}

While potential absorptive capacity increases strategic flexibility, realized absorptive capacity manifests in stronger innovation performance (Zahra \& George, 2002). In particular, once external knowledge is acquired and assimilated (potential absorptive capacity), that knowledge needs to be 
transformed and exploited, i.e., new insights and consequences through combining existing and new knowledge, and incorporating new knowledge in operations (Jansen et al., 2005; Zahra \& George, 2002). Realized absorptive capacity enables a company to innovate and create value (Khan, Lew, \& Marinova, 2019). As formulated in H1, potential absorptive capacity is an antecedent of realized absorptive capacity, which then drives innovation. A firm's ability to acquire and assimilate new knowledge increases the knowledge base, while the ability to transform and exploit it enables the firm to innovate. While this conceptual understanding is widely accepted, there is limited empirical evidence. Some recent studies found that realized absorptive capacity is an antecedent of exploitative and exploratory innovation, green product and process innovation (Albort-Morant, Henseler, Cepeda-Carrión, \& Leal-Rodríguez, 2018), and new business creation and self-renewal (e.g., reformulation of strategies, redefinition of businesses) (Sun \& Anderson, 2011). Leal-Rodríguez, Ariza-Montes, Roldán, and Leal-Millán (2014), and Limaj and Bernroider (2019) found that the path from potential absorptive capacity to innovation is fully mediated by realized absorptive capacity.

To the best of our knowledge, no study has investigated the role of realized absorptive capacity in BMI adoption. BMI "can range from incremental changes in individual components of business models, extension of the existing business model, introduction of parallel business models, right through to disruption of the business model, which may potentially entail replacing the existing model with a fundamentally different one" (Khanagha et al., 2014, p. 324). Hence, a firm's ability to innovate its business model could strongly depend on how well it is able to combine existing with new knowledge, and apply it to "refine, extend, and leverage existing competences or to create new ones by incorporating acquired and transformed knowledge into its operations" (Zahra \& George, 2002, p. 190). Thus, we expect that realized absorptive capacity has a positive impact on BMI. Formally stated: 
H3: Realized absorptive capacity is positively associated with BMI.

\subsection{Strategic flexibility and business model innovation}

Strategic flexibility emphasizes the flexible reallocation and reconfiguration of resources, processes, and strategies to cope with external changes (Zhou \& Wu, 2010), thereby reflecting a type of dynamic capability (Eisenhardt \& Martin, 2000). Strategic flexibility is considered a key determinant of competitive advantage in turbulent markets (Hitt et al., 1998).

The strategic flexibility literature takes either a reactive or proactive perspective. The former describes a firm's ability to react to environmental changes, and the latter the ability to model, shape, or transform the environment (Brozovic, 2018). Research shows that strategically flexible organizations are known for their ability to recognize new technological knowledge, assimilate and apply it to their products or service interfaces, leading to modular operation systems (Sanchez \& Mahoney, 1996). While some studies see strategic flexibility as a consequence of BMI (e.g., Schneider \& Spieth, 2014), we refer to the literature that considers flexibility as an antecedent of BMI (e.g., Bock et al., 2012; Clauss et al., 2019). BMI aims at "consciously renewing a firm's core business logic rather than limiting its scope of innovation on single products or services" (Schneider \& Spieth, 2013). Firms engaged in BMI are challenged to develop new business ideas and to (re)deploy and use resources and capabilities to develop new value offerings (Clauss, 2017; Schneider \& Spieth, 2013), integrating all business model elements, the external environment, and the interfaces with customers and partners (Zott \& Amit, 2010). Such a comprehensive change requires high levels of strategic flexibility, i.e., the dynamic capability to cope with environmental change by reallocating and reconfiguring the firm's resources, processes, and strategies (Sanchez, 1995).

The idea that strategic flexibility is an important driver of different types of innovation has 
received substantial empirical support. For example, strategically flexible firms in the home appliance industry develop different models of vacuum cleaners, washing machines, freezers, and refrigerators by mixing and matching key components in different combinations (Worren et al., 2002). Other studies show that strategic flexibility also supports new product development (Kandemir \& Acur, 2012), radical innovation (Medina, Lavado, \& Cabrera, 2006), innovation performance (Fan et al., 2013), and explorative innovation types (Zhou \& Wu, 2010), well-known outcomes of both potential and realized absorptive capacity (Cohen \& Levinthal, 1990; Zahra \& George, 2002). Hence, building on these arguments and the empirical evidence on the role of strategic flexibility for innovation, we postulate:

H4: Strategic flexibility is positively associated with BMI.

Figure 1 summarizes the hypothesized relationships.

(Insert Figure 1 about here)

\section{Methodology}

\subsection{Sample}

For our research purposes, we collected data on Italian SMEs focusing on BMI activities for two main reasons. First, Italy has implemented a rich policy mix (R\&D tax credits, industrial district development, support for start-ups, and many others) and an ambitious policy strategy of supporting R\&D, technology, and innovation (Lucchese, Nascia, \& Pianta, 2016). Second, we focus specifically on SMEs because it is widely acknowledged that they are the backbone of the Italian economy (Muller, Julius, Herr, Koch, Peycheva, \& McKiernan, 2017), and important developers of innovation (Massa \& Testa, 2008), thereby representing a good research laboratory for our study.

Following prior research (e.g. Howorth \& Moro, 2012), a random sample of 1300 firms with up 
to 250 employees and total annual revenues between 1 and 50 million euro, corresponding to the European Commission's definition of micro-, small- and -medium-size enterprises (European Commission Recommendation 2003/361/EC), was extracted from the Italian Digital Database of Companies (AIDA).

We developed a survey questionnaire that two researchers translated from English into Italian through a forward- and back-translation procedure. The questionnaire was subsequently pilottested on four university researchers and three SMEs. Their observations on the content, item wording, terminology, and clarity were incorporated in a revised survey. Finally, the revised survey was cross-checked by the professional company that carried out the phone survey and ensured its high quality (e.g. Arzubiaga, Kotlar, De Massis, Maseda, \& Iturralde, 2018).

The data collection process lasted four months from September to December of 2018. The response rate was 23\%, giving us 300 completed surveys of which 18 were not usable due to missing data, leaving us with a final sample of 282 respondents. The response rate is consistent with prior research on SMEs (Classen, Carree, Van Gils, \& Peters, 2013; Kellermanns, Eddleston, Sarathy, \& Murphy, 2012), including studies on Italian SMEs (Cucculelli \& Bettinelli, 2015). We assessed potential non- or late-response bias according to Armstrong and Overton (1977). As only one survey item showed significant differences, non-response bias is not deemed a serious concern (Armstrong \& Overton, 1977). We also compared early and late respondents in terms of demographics, and found no significant differences $(p<.05)$, indicating that differences between respondents were not related to non-response bias.

Most firms in our sample are SMEs (92.3\%), while micro-enterprises represent only around $7.7 \%$. In terms of economic activity, more than $40 \%$ of firms belong to the manufacturing sector and the remainder are non-manufacturing firms. Like prior research on Italian private firms (e.g. De Massis, Kotlar, Campopiano, \& Cassia, 2013), the majority of firms in our sample are based in 
northern Italy (72\%), while only $17 \%$ and $11 \%$ are based in central and southern Italy, respectively. Looking at the organizational role of our respondents, $19 \%$ of the sample are owners or co-owners of the firm, $23 \%$ are managing directors or general managers, and around $21 \%$ R\&D managers. The remainder have other managerial roles.

\subsection{Measurement}

We operationalized our model using measurement scales established and validated in prior studies.

Absorptive capacity: Potential absorptive capacity refers to knowledge acquisition and assimilation, and realized absorptive capacity to knowledge exploitation and transformation (Jansen et al., 2005). To measure absorptive capacity, we adapted the scale of Flatten, Engelen, Zahra, and Brettel (2011). Overall, the measure is based on 14 items covering the subdimensions knowledge acquisition (3 items), knowledge assimilation (4 items), knowledge exploitation (3 items), and knowledge transformation (4 items). Respondents rated their level of agreement on a 5-point Likert-type scale $(1=$ strongly disagree; $5=$ strongly agree $)$. These first order dimensions are reflective measures (Flatten et al., 2011). Table 1 presents the items together with their psychometric properties. Potential absorptive capacity was measured as a formative second order construct consisting of the knowledge acquisition and knowledge assimilation subdimensions. Realized absorptive capacity was measured as a formative second order construct consisting of the knowledge exploitation and knowledge transformation subdimensions.

Strategic flexibility: Following Liu, Jiang, Zhang, and Zhao (2013, p. 86), strategic flexibility captures "the ability to adjust available means to better achieve current and expected future ends, in accordance with an encountered situation". As such, measures of strategic flexibility mirror the proactive and reactive abilities of firms reacting to environmental changes (Brozovic, 2018). We 
adapted six items from previous research measuring the proactive and reactive ability to meet changing environmental conditions (Grewal \& Tansuhaj, 2001; Liu et al., 2013; Nadkarni \& Herrmann, 2010). Respondents were asked to rate their level of agreement with six items on a 5point Likert-type scale $(1=$ strongly disagree; $5=$ strongly agree) $($ see Table 1$)$.

Business model innovation: While scholars have shown considerable interest in BMI in the last two decades, validated measurement scales have only been developed quite recently (e.g., Clauss, 2017). Generally, BMI measurement models consider the construct to be composed of three main dimensions measuring innovation in terms of value creation or architecture, value proposition or offering, and value capture or revenue models (Clauss, 2017; Spieth \& Schneider, 2016). While the measures are consistent in terms of what they measure, they vary considerably in terms of length. We opted for a short and concise measure, as lengthy surveys yield lower response rates (Burchell \& Marsh, 1992), and achieving acceptable response rates is deemed critical. Thus, for this study, the BMI scale was taken from Spieth and Schneider (2016). Based on 9 items, the scale measures the extent of BMI over a period of 3 years across the dimensions of value offering innovation (3 items), value architecture innovation (4 items), and revenue model innovation (2 items). Thus, BMI is a formative second order construct based on three formative first order dimensions. Respondents were asked to rate to what extent the BMI facets had changed in the last 3 years $(1=$ not at all; $5=$ completely). Table 2 presents the items together with the statistics for evaluating formative measures for the first order dimensions of BMI, and Table 3 presents the statistics for the formative second order construct.

Control variables: As innovation activities and strategic flexibility depend on the organizational and environmental context, we included a set of control variables in our analysis. First, there is evidence that family firms, a dominant type of organization around the globe (De Massis, Frattini, Majocchi, \& Piscitello, 2017), differ with respect to innovation (Matzler, Veider, Hautz, \& Stadler, 
2015; Strobl, Matzler, Nketia, \& Veider, 2018) and strategic flexibility (Zahra, Hayton, Neubaum, Dibrell, \& Craig, 2008). Thus, we controlled for family ownership measured as the percentage shares held by the focal family. We also included a dummy variable indicating whether a company handover was planned in the coming 3 to 5 years, since this may affect strategy and innovation activities (Domínguez-CC \& Barroso-Castro, 2016; Grundström, Öberg, \& Rönnbäck, 2012). Furthermore, firm size and firm age might play a role in a firm's propensity to adopt BMI (Kellermanns et al., 2012; Zahra et al., 2008), and shape strategic flexibility (Dean, Brown, \& Bamford, 1998; Miller \& Friesen, 1984). Firm size was measured along six revenue categories (1 $=<1$ Mil. EUR; $2=1-5$ Mil. EUR; 3 = 5-10 Mil. EUR; $4=10-20$ Mil. EUR; 5 = 20-30 Mil. EUR; $6=30-40$ Mil. EUR). Firm age was measured as the number of years since its foundation. Environmental conditions are associated with innovation activities in general (Damanpour, 1996), and BMI in particular (Clauss et al., 2019). Thus, we adapted an item from Miller and Dröge (1986) measuring the amount of change in the environment on a 5-point Likert-type scale $(1=$ the production/service technology is not subject to very much change and is well established; $5=$ the modes of production/service change often and in a major way) (e.g., advanced electronic components).

(Insert Tables 1, 2, \& 3 about here)

\subsection{Method}

To test our hypotheses, we performed partial least squares (PLS) structural equation modelling (SEM), as our study relies on formative first order and second order measurement models. PLS SEM has advantages in handling such measurement models (Hair, Sarstedt, Ringle, \& Mena, 2012), particularly as the survey items are not normally distributed and PLS does not require a strict normal distribution of items (Hair, Hult, Ringle, \& Sarstedt, 2014). On average, the items of the latent variables showed an absolute value of skewness of .31 and kurtosis of .58 . To conduct 
the analyses, we used the SmartPLS 3.2.8 software (Ringle, Wende, \& Becker, 2015). PLS SEM relies on bootstrapping when testing for significance (Henseler, Ringle, \& Sinkovics, 2009), and following Hair et al. (2012), all our calculations are based on 5,000 bootstrap runs.

\section{Results}

\subsection{Measurement model evaluation}

Before testing our hypotheses, we investigated the reliability and validity of the measurement model. Our model contains reflective and formative measurement specifications. Potential and realized absorptive capacity are specified as type II hierarchical latent variables, meaning that the higher order construct (i.e., potential absorptive capacity) is formative, and the lower order constructs reflective (i.e., knowledge acquisition) (Becker, Klein, \& Wetzels, 2012). BMI is specified as a type IV hierarchical latent variable. Thus, the higher order construct (BMI) and the lower order constructs are formative measures (i.e., value architecture innovation) (Becker et al., 2012). Strategic flexibility is a reflective first order measure. We first assessed the reliability and validity of the reflective first order variables before evaluating the formative first and second order constructs.

For the reflective measurement models, we investigated the composite factor loadings, composite reliability (CR), average variance extracted (AVE), and the Fornell-Larcker Ratio as an indicator of discriminant validity (Bagozzi \& Yi, 1988; Fornell \& Larcker, 1981; Hair et al., 2012). These investigations led to making minor adjustments to the measurement model. More precisely, one item of the absorptive capacity subdimension knowledge acquisition had to be excluded. The final measurement model exceeds the commonly proposed thresholds for loadings, CRs and AVEs (Bagozzi \& Yi, 1988; Hair et al., 2012). The loadings range from .73 to .90, AVEs from .70 to .81, and CRs from .87 to .94 (see Table 1). 
To evaluate the formative measurement models, we followed the recommendations of Hair et al. $(2012,2014)$ and investigated the indicator weights together with the T-statistics and outer model variance inflation factors (VIFs). All indicators show positive and highly significant weights, indicating item relevance for explaining the latent variable. The weights of the indicators vary slightly, pointing towards differences in the importance of the specific indicators to explain a respective latent variable. For instance, the item "the product and service offering has changed" (weight $=.51)$ is slightly more important for the BMI value offering innovation dimension compared to the other two items (weights $=.36$ and .38 ). All indicator VIFs are well below 2, which is below the threshold of 5 proposed in the literature (Hair et al., 2012, 2014). Thus, the formative measures do not show any multicollinearity violations. The results support the validity of the formative first order measurement models (see Table 2).

The higher order formative constructs were assessed according to the repeated indicator approach with mode B (Becker et al., 2012) where the indicators of the lower order constructs are used to identify the higher construct. Consequently, the paths between the lower order constructs (i.e., revenue model innovation, value architecture innovation, and value offering innovation) and the higher order construct (i.e., BMI) represent the formative construct weights (Becker et al., 2012). As for the lower order constructs, we investigated the significance and VIFs of the weights (Sarstedt, Hair, Cheah, Becker, \& Ringle, 2019). The results support the validity of the higher order constructs. All lower order dimensions show highly significant and positive weights. Furthermore, the VIFs again are well below the commonly proposed thresholds (e.g., Hair et al., 2012) (see Table $3)$.

We also investigated the discriminant validity of the measurement model. For the first order constructs, following Fornell and Larcker (1981), we compared the square root of the AVEs with the latent variable correlations (see Table 4). Note that for the subdimensions of BMI, no AVEs 
could be calculated due to the formative measurement specification. However, the correlations of the BMI subdimensions with other variables are rather low. Furthermore, the rather high correlations between the three subdimensions are not problematic as they are part of the same higher order construct (i.e., BMI), and the VIFs do not point to any measurement problems (see Table 3). As all the other latent variable correlations are lower than the square roots of the respective AVEs of the reflective measures, the measurement model shows discriminant validity (Fornell \& Larcker, 1981). We also checked the cross loadings between the latent variables (Chin, 1998). All items loaded highest on the proposed constructs. Finally, we also investigated the latent variable correlations between the higher order constructs and the other variables of interest in the structural model (see Table 5). The correlations do not exceed the recommended threshold of .65 (Tabachnick \& Fidell, 2012). Thus, these analyses do not provide any evidence of reliability and validity violations (see Tables 4 and 5).

(Insert Tables 4 and 5 about here)

\subsection{Common method bias analyses}

In cross sectional studies based on survey data, common method bias may occur. Thus, we tested for this issue and included a common method factor in our model (Podsakoff, MacKenzie, Lee, \& Podsakoff, 2003; Williams, Edwards, \& Vandenberg, 2003). To conduct this analysis with PLS, we followed the proposition of Liang, Saraf, Hu, and Xue (2007) and compared the substantive item loadings on the respective latent constructs to the item loadings on the method factor ${ }^{1}$. While all the items load high (.70 to .94) and significantly on the proposed latent variables, the common method factor loadings are low (-.18 to .20$)$ and mostly non-significant. On average, the items loaded .75 on the latent variables and .00 on the method factor, yielding a ratio of 151.44:1.

\footnotetext{
${ }^{1}$ According to Liang et al. (2007), this is also suitable with formative measures when changing the measurement models to reflective ones does not lead to substantial changes. This was the case in our study. Recalculating the model with reflective measurement models yielded very similar path coefficients and significance levels.
} 
According to this analysis, common method bias is not an issue in our study.

\subsection{Hypothesis testing}

In situations when models contain endogenous formative higher order constructs (i.e., BMI), the repeated indicator approach requires some additional analysis, since "all variance of the higher order component is explained by its lower order components" (Ringle, Sarstedt, \& Straub, 2012, p. S8). We therefore followed the propositions of Ringle et al. (2012). To investigate the structural model relationships, the latent variable scores of the lower order constructs derived from investigating the measurement model were used as formative indicators of the higher order models $^{2}$. Thus, BMI, potential absorptive capacity, and realized absorptive capacity are formatively composed of the latent variable scores of their lower order dimensions.

For the structural model, we investigated the path estimates, T-statistics, $\mathrm{f}^{2}$ effect sizes and VIFs. $\mathrm{f}^{2}$ effect sizes indicate to what extent a variable contributes to the $\mathrm{R}^{2}$ of an endogenous construct (Hair et al., 2012, 2014). We used the VIFs to check for potential multicollinearity issues in the structural model. The VIFs range between 1.00 to 1.74 , and are well below the commonly proposed threshold of 10 (e.g., O’Brien, 2007). Table 6 presents these calculations.

To test our hypotheses, we calculated three models to see how the explained variance of the endogenous variables develops. Model 1 contains only the control variables, Model 2 includes the hypothesized relationships presented in Figure 1, and Model 3 investigates the robustness of the hypothesized relationships by additionally controlling for influences of potential absorptive capacity on BMI and realized absorptive capacity on strategic flexibility.

Model 1 shows that the control variables contribute reasonably to explaining BMI $\left(\mathrm{R}^{2}=.16\right)$, but only minimal power in explaining strategic flexibility $\left(\mathrm{R}^{2}=.04\right)$. Supporting previous research

\footnotetext{
${ }^{2}$ For a more detailed explanation, see Ringle et al. (2012) and Sarstedt et al. (2019).
} 
(Clauss et al., 2019), environmental uncertainty shows particular explanatory power $(\beta=.30$, Tstatistic $=4.97)$ contributing most of the explaining variance $\left(\mathrm{f}^{2}=.10\right)$ of BMI in Model 1. Company handover $\left(\beta=-.14\right.$, T-statistic $\left.=2.04, \mathrm{f}^{2}=.02\right)$ and firm size $(\beta=.22$, T-statistic $=3.49$, $\left.\mathrm{f}^{2}=.05\right)$ also exert significant influence, but with lower explanatory power. In terms of strategic flexibility, family ownership shows a significant negative influence $\left(\beta=-.15\right.$, T-statistic $=2.37, \mathrm{f}^{2}$ $=.02$ ). Model 2 shows that the explained variance increases when including the hypothesized relationships. While the increase for $\mathrm{BMI}\left(\mathrm{R}^{2}=.18\right)$ is marginal, the increase for strategic flexibility is substantial $\left(\mathrm{R}^{2}=.26\right)$. Model 2 shows that potential absorptive capacity is a strong and significant driver of realized absorptive capacity $\left(\beta=.55\right.$, T-statistic $\left.=11.33, \mathrm{f}^{2}=.43\right)$ and strategic flexibility $\left(\beta=.48, \mathrm{~T}\right.$-statistic $\left.=8.95 ; \mathrm{f}^{2}=.31\right)$. Strategic flexibility $\left(\beta=.12, \mathrm{~T}\right.$-statistic $\left.=1.86, \mathrm{f}^{2}=.01\right)$ shows a positive significant influence on BMI. The effect of realized absorptive capacity on BMI is not significant. Model 3 shows that controlling for possible influences of potential absorptive capacity on BMI and realized absorptive capacity on strategic flexibility not only increases the explained variance of BMI $\left(\mathrm{R}^{2}=.21\right)$ and strategic flexibility $\left(\mathrm{R}^{2}=.35\right)$, but also provides a clearer picture of the hypothesized relationships. Thus, the additional paths are relevant for explaining both endogenous constructs. The inclusion of these effects reveals that the influence of strategic flexibility on BMI is not robust, as the effect is no longer significant $\left(\beta=.06\right.$, T-statistic $=.90, \mathrm{f}^{2}$ $=.00)$. Instead, potential absorptive capacity drives BMI and shows explanatory power $(\beta=.23$, $\mathrm{T}$-statistic $\left.=3.04, \mathrm{f}^{2}=.04\right)$. Thus, the significant influence and explanatory power of strategic flexibility in Model 2 stem from a forced mediation of the influence of potential absorptive capacity. Additionally, Model 3 shows that realized absorptive capacity also substantially drives strategic flexibility $\left(\beta=.37, \mathrm{~T}\right.$-statistic $\left.=6.10, \mathrm{f}^{2}=.14\right)$. Thus, contrary to the theoretical propositions in the literature (Zahra \& George, 2002), Model 3 shows that only potential absorptive capacity drives BMI. In addition, we find that realized absorptive capacity, besides potential 
absorptive capacity, also increases a company's strategic flexibility. The other effects identified in Model 2 remain significant with minor changes in magnitude. Table 6 summarizes these calculations.

\section{(Insert Table 6 about here)}

In summary, H1 predicted a positive relationship between potential and realized absorptive capacity. Models 2 and 3 show a stable positive and significant effect (see Table 6). Thus, H1 is fully supported. H2 predicted that potential absorptive capacity drives an organization's strategic flexibility. Again, we find a highly significant and positive relationship in Models 2 and 3. Thus, $\mathrm{H} 2$ is supported. $\mathrm{H} 3$ predicted that realized absorptive capacity drives BMI. Models 2 and 3 show insignificant path coefficients. Thus, H3 is rejected. Finally, H4 predicted that strategic flexibility increases BMI. The results of this study do not confirm this relationship. Although, Model 2 shows a significant and positive relationship $\left(\beta=.12\right.$, T-statistic $\left.=5.15, \mathrm{f}^{2}=.01\right)$, this result is not confirmed in Model 3. Thus, H4 is rejected.

In conclusion, our study highlights environmental uncertainty, firm size (measured by revenue), and potential absorptive capacity as salient drivers of BMI, while company handover diminishes BMI. Potential and realized absorptive capacity are the main drivers of strategic flexibility, while family ownership decreases strategic flexibility. Figure 2 summarizes the results of Model 3.

(Insert Figure 2 about here)

\subsection{Post-hoc analyses}

For a better understanding of the relationships between absorptive capacity, BMI, and strategic flexibility, we also investigated potential mediating influences. Based on Model 3, we calculated the estimates, T-statistics, and 95\% bias-corrected confidence intervals (BCI) for the indirect and total effects (MacKinnon, Lockwood, Hoffman, West, \& Sheets, 2002; Zhao, Lynch, \& Chen, 2010). The mediation is considered significant when the respective bias-corrected confidence 
interval does not include zero (Zhao et al., 2010). This analysis yielded one additional significant influence. The indirect effect between potential absorptive capacity and strategic flexibility is positive and highly significant $(\beta=.20$, T-statistic $=5.15,95 \% \mathrm{BCI}=.13$ to .28$)$. The total effect of potential absorptive capacity on strategic flexibility is therefore .49 ( $\mathrm{T}$-statistic $=9.28,95 \% \mathrm{BCI}$ $=.38$ to .58$)$. Following Zhao et al. (2010), we find a complementary mediation. Thus, the influence of potential absorptive capacity on BMI is partly mediated through realized absorptive capacity.

Zahra and George (2002) highlight that external influences, such as competitive dynamics, affect the outcomes of absorptive capacity. Clauss et al. (2019) show that environmental turbulence is an important contingency factor in the context of BMI, arguing that "firms in such environments operate under constant pressure to not only respond quickly to changing market conditions but also learn to proactively anticipate and adapt" (p. 4). Thus, we conducted some further post-hoc analyses. Specifically, we investigated potential moderating effects of our control variable environmental uncertainty on the effects of potential and realized absorptive capacity on strategic flexibility and BMI, respectively. Model 4 in Table 6 presents these calculations. This analysis yielded one further significant relationship. Environmental uncertainty positively moderates the relationship between realized absorptive capacity and BMI $(\beta=.12$, T-statistic $=1.90)$. Thus, our results indicate that realized absorptive capacity drives BMI only under uncertain environmental conditions (see Figure 3). The inclusion of the moderating relationships increases the $\mathrm{R}^{2}$ of $\mathrm{BMI}$ only slightly to .22 . While these results should be treated with caution as the moderating variable is a single item measure, they provide an interesting starting point for future research initiatives.

(Insert Figure 3 about here)

\subsection{Inner model evaluation}

We also evaluated the inner model in terms of $\mathrm{q}^{2}$ effect sizes (see Tables 7 and 8), showing the power of a variable for predicting an endogenous construct (Hair et al., 2012, 2014). The $\mathrm{q}^{2}$ effect 
sizes are based on a blindfolding procedure following the cross-validated redundancy approach (Hair et al., 2012, 2014). We undertook this analysis based on the results of Model 4 in Table 6, as this model explains the greatest variance of the endogenous variables BMI and strategic flexibility. Based on an omission distance of 7, which meets the criteria of lying between 5 and 10 , and not being a multiple of the sample size $(\mathrm{N}=282)$ (Hair et al., 2012, 2014), we find positive effect sizes for the significant relationships indicating their predictive relevance. While potential absorptive capacity $\left(\mathrm{q}^{2}=.02\right)$ and the control variables company handover $\left(\mathrm{q}^{2}=.02\right)$, environmental uncertainty $\left(\mathrm{q}^{2}=.05\right)$, and firm size $\left(\mathrm{q}^{2}=.02\right)$ are relevant for predicting BMI, potential $\left(\mathrm{q}^{2}=.04\right)$ and realized absorptive capacity $\left(\mathrm{q}^{2}=.08\right)$ are relevant for predicting strategic flexibility. The effect sizes are weak to moderate (Hair et al., 2012, 2014). Tables 7 and 8 summarize these analyses.

(Insert Tables 7 and 8 about here)

\section{Discussion and implications}

This research has investigated internal drivers of BMI and strategic flexibility in Italian SMEs. Specifically, the potential and realized absorptive capacity dimensions are considered drivers of flexibility and various forms of innovation. Following the common conceptualization of absorptive capacity as a dynamic capability (Zahra \& George, 2002) helping firms boost innovation (CepedaCarrion et al., 2012; Kostopoulos et al., 2011), we show that absorptive capacity is an important prerequisite of BMI and strategic flexibility, which are salient drivers of competitive advantage (Zahra \& George, 2002). However, only potential absorptive capacity (i.e., the acquisition and assimilation of knowledge) drives BMI. Furthermore, we find that potential absorptive capacity directly and indirectly influences strategic flexibility through realized absorptive capacity. Thus, we find support for our argument on the importance of internal drivers, and identify important antecedents of BMI in SMEs scarcely studied in the literature (Foss \& Saebi, 2017).

The potential absorptive capacity of SMEs generally increases their capacity to access, 
internalize, and exploit new knowledge, as well as their flexibility. However, BMI in SMEs requires a constant renewal of the firm's knowledge stock (potential absorptive capacity; Jansen et al., 2005), while transforming and exploiting this knowledge (realized absorptive capacity; Jansen et al., 2005) is not a prerequisite. These findings point out that transforming and exploiting knowledge through the development of new or improved products and services does not necessarily lead to a change in the overall business model. Moreover, our findings sustain real-world observations of product innovations and updates brought to the market using existing business logics and channels. For instance, the Italian family business Vibram transformed and exploited knowledge of high performance rubber soles by developing the Fivefingers footwear (De Massis, Frattini, Kotlar, Petruzzelli, \& Wright, 2016). However, major parts of their business model, including revenue models, core competences, partnerships, distribution channels, target customers, and company positioning remained largely unchanged. This example explains our non-significant relationship between realized absorptive capacity and BMI by demonstrating that knowledge transformation and exploitation might not necessarily lead to changes in the business model.

The interesting finding of a non-significant relationship between realized absorptive capacity and BMI raises several questions. Zahra and George (2002), amongst others (e.g., Todorova \& Durisin, 2007), argue that absorptive capacity translates into competitive advantage under specific conditions. A potential explanation for the absence of the effect of realized absorptive capacity on BMI is the conceptualization of realized absorptive capacity, which strongly focuses on product, process, and technology aspects. BMI, however, also includes a value capture dimension (revenue and cost mechanisms; Spieth \& Schneider, 2016). In the context of BMI, it may be necessary to extend the conceptualization of absorptive capacity to knowledge elements related to all dimensions of BMI. However, our post-hoc analysis suggests that there might be a link between realized absorptive capacity and BMI in uncertain environments where changes in products and 
services are frequent and substantial. Thus, under such conditions, new and enhanced products and services might also require changing the business model, which might help firms establish what Zahra and George (2002) call "strong regimes of appropriability", referring to the institutional and industry dynamics that affect the firm's ability to safeguard the advantages derived from realized absorptive capacity. Our results point to the fact that BMI might be a way to establish such a favorable context.

The unexpected and interesting finding of a non-significant nexus between strategic flexibility and BMI also raises new research questions. Several scholars show that more flexible organizations are in a better position to adopt BMI in the electronics (Clauss et al., 2019) or information and technology industries (Doz \& Kosonen, 2008) characterized by an extremely high pace of change and technological innovation. While our empirical analysis covering a wide range of industrial sectors (including both manufacturing and non-manufacturing firms) does not confirm the aforementioned findings, it suggests that the effect of strategic flexibility is likely to be present only in industrial sectors with high technological intensity. Hence, future studies could examine industrial heterogeneity in the context of the strategic flexibility and BMI relationship, and the persistence of this relationship over time.

\subsection{Theoretical implications}

Several theoretical implications derive from this study. Our findings fundamentally expand prior knowledge on the internal antecedents of BMI by showing the importance of absorptive capacity. As such, this study enriches the BMI literature by offering insights into the widely neglected field of internal drivers, and establishes the basis for future research on the impact of dynamic capabilities on innovation performance. We empirically show that innovation in terms of a firm's business model is not dependent on realized absorptive capacity, but only on potential absorptive 
capacity, thereby adding to the existing theoretical absorptive capacity model of Zahra and George (2002). However, our study also points to the fact that the relationship between realized absorptive capacity and BMI could be contingent on environmental uncertainty. We reason that in such an environment, BMI might help firms protect the benefits stemming from realized absorptive capacity. Thus, our study reveals that the nature and magnitude of the relationship between different types of absorptive capacity and innovation is more complex than previously thought, and might depend on the type of innovation (e.g., BMI vs product or service innovation) and contextual issues (e.g., environmental uncertainty). Therefore, we encourage future scholars to empirically examine the theoretical propositions of Zahra and George (2002) to obtain a more fine-grained understanding of the absorptive capacity-innovation relationship. Ideally, future scholars would use contingency perspectives to examine the determinants, processes, and outcomes of absorptive capacity (e.g., Kotlar, De Massis, Frattini, \& Kammerlander, 2020).

Furthermore, BMI dynamics of large companies received substantial attention in prior research (Block et al., 2011; Kastalli \& Van Looy, 2013), while our paper examines the interplay between absorptive capacity and strategic flexibility in renewing BMI in the context of SMEs, one of the driving forces of Europe's economy (Crespo, 2014). In so doing, this study enriches and expands the BMI literature, and encourages future research on BMI in the SME context.

Another interesting aspect of our work is that we shed light on absorptive capacity as a previously overlooked determinant of strategic flexibility. Specifically, our study demonstrates that potential absorptive capacity directly and indirectly (via realized absorptive capacity) affects a firm's strategic flexibility. Thus, besides building innovation potential through enriching the firm's knowledge base, the realization of this potential in terms of new products and services also makes firms more flexible in a strategic sense. Thus, our study identifies a novel driver determining the level of organizational strategic flexibility, thereby expanding Brozovic's (2018) list of resource- 
related enablers of strategic flexibility. To sum up, we add to the growing knowledge highlighting the importance of absorptive capacity in overcoming organizational inertia and demolishing institutional routines to achieve competitive advantage in the marketplace (e.g. Liao, Welsch, \& Stoica, 2003).

\subsection{Managerial implications}

A number of managerial implications ensue from our study suggesting that corporate managers need to understand how different components of absorptive capacity relate to strategic flexibility, and how these components shape a firm's BMI. Thus, firms with better absorptive capacity have advantages in sustaining competitive advantage through BMI and strategic flexibility. Furthermore, different types of absorptive capacity do not play the same role in this respect. In particular, potential absorptive capacity plays a noteworthy role as a driver of competitive advantage, BMI, and strategic flexibility. Our results show that BMI is particularly dependent on potential absorptive capacity, since firms tend to prioritize knowledge acquisition and knowledge assimilation over knowledge transformation and knowledge exploitation. Thus, gaining access to knowledge, adapting and incorporating knowledge in the current business are key to innovating the business model and creating strategic flexibility. Managers should equip their human resources with suitable knowledge acquisition and assimilation tools. Providing opportunities to access external knowledge sources (e.g., enabling employees to take part in industry specific meetings) and spreading such knowledge throughout the organization (e.g., through cross-departmental meetings) should foster potential absorptive capacity in SMEs.

Managers should also be aware that realized absorptive capacity is a salient driver of strategic flexibility. Exploiting and transforming knowledge (e.g., through process and product innovations) provides SMEs with further strategic options. Our findings also suggest that business consultants 
advising SMEs should consider the importance of possible relationships between strategic flexibility and the different components of absorptive capacity when providing advice and support on the topic of BMI. Finally, managers acting in very dynamic environments should consider complementing service and product innovations with business model innovations to protect themselves from competitor imitation.

\subsection{Limitations and future research}

This study is subject to some limitations that offer valuable indications for future research. First, our findings are based on a sample of Italian SMEs. While a uniform institutional and cultural context helps minimize biases, it might pose limitations to the generalizability of our results to different types of organizations and other regions with different cultural and institutional environments. Further empirical efforts are needed to test our theoretical framework across publicly-traded firms and different geographic regions.

Second, the cross-sectional design of our study based on key informants has some limitations and potential causality issues. Although we performed a wide range of controls of our explanatory model to rule out potential alternative explanations, future research could investigate the robustness of our findings with the help of different research designs (e.g., longitudinal or experimental) or different data sources (e.g., archival data). In addition, future qualitative or mixed-method studies could also shed more light on the interplay between absorptive capacity, strategic flexibility, and BMI (De Massis \& Kotlar, 2014).

Finally, we expect other variables to have an impact on BMI. On the one side, although research on drivers of BMI is still scarce, some preliminary attempts point to some variables of interest, such as organizational values or culture (Foss \& Saebi, 2017). Our empirical results with respect to the control variables used in our model also provide some cues. We found a significant negative 
effect of upcoming company handover on BMI. We reason that SMEs facing major internal changes simply do not have additional capacities to simultaneously engage in innovation activities. Thus, future research could examine BMI adoption across the firm's lifecycle to better understand how different organizational stages affect BMI. In addition, we found that firm size is a significant predictor of BMI, implying that larger firms are in a better position to adopt BMI than smaller ones. In this context, a potential research avenue is exploring the connection between BMI adoption and firm-size heterogeneity. Our study also reveals that family firms exhibit lower levels of strategic flexibility than their non-family counterparts. This may be explained by the fact that family firms are typically resistant to change (Bozzi, Barontini, \& Miroshnychenko, 2017; Chirico \& Salvato, 2008), even when change is strongly needed. Therefore, future studies could attempt to understand how BMI is developed in different types of family firms considering their level of strategic flexibility and resistance to change (Bozzi et al., 2017; De Massis, Sharma, Chua, \& Chrisman, 2012).

Furthermore, some possible moderators might be explored to obtain a better understanding of the relationship between absorptive capacity and BMI, such as regimes of appropriability (i.e., institutional and industry dynamics, such as intellectual property rights and ease of replication, which influence a firm's ability to translate absorptive capacity into competitive advantage), and power relationships. In addition, strong commitment to existing customers and other stakeholders might explain why companies fail to capitalize on new knowledge, which may hinder BMI. When resource allocation processes are too focused on current customers and existing stakeholder relationships, realized absorptive capacity (i.e., knowledge exploitation and transformation) might become ineffective for BMI. Internal power relationships, due to idiosyncrasies including ownermanagement relationships, informality, personal relationships (Russo \& Perrini, 2010), or commitment to the existing customer base (and other stakeholders) (e.g., Perrini, 2006), may differ 
in SMEs, and might further explain the link between absorptive capacity and BMI. Hence, future studies could investigate the role of these moderating influences.

\section{References}

Albort-Morant, G., Henseler, J., Cepeda-Carrión, G., \& Leal-Rodríguez, A. (2018). Potential and realized absorptive capacity as complementary drivers of green product and process innovation performance. Sustainability, 10(2), 381. https://doi.org/10.3390/su10020381

Ali, M., Seny Kan, K. A., \& Sarstedt, M. (2016). Direct and configurational paths of absorptive capacity and organizational innovation to successful organizational performance. Journal of Business Research, 69(11), 5317-5323. https://doi.org/10.1016/j.jbusres.2016.04.131

Armstrong, J. S., \& Overton, T. S. (1977). Estimating nonresponse bias in mail surveys. Journal of Marketing Research, 14(3), 396-402. https://doi.org/10.2307/3150783

Arzubiaga, U., Kotlar, J., De Massis, A., Maseda, A., \& Iturralde, T. (2018). Entrepreneurial orientation and innovation in family SMEs: Unveiling the (actual) impact of the board of directors. Journal of Business Venturing, 33(4), 455-469.

https://doi.org/10.1016/j.jbusvent.2018.03.002

Bagozzi, R. P., \& Yi, Y. (1988). On the evaluation of structural equation models. Journal of the Academy of Marketing Science, 16(1), 74-94. https://doi.org/10.1007/BF02723327

Becker, J.-M., Klein, K., \& Wetzels, M. (2012). Hierarchical latent variable models in PLS-SEM: Guidelines for using reflective-formative type models. Long Range Planning, 45(5), 359-394. https://doi.org/10.1016/j.lrp.2012.10.001 
Bock, A. J., Opsahl, T., George, G., \& Gann, D. M. (2012). The effects of culture and structure on strategic flexibility during business model innovation. Journal of Management Studies, 49(2), 279-305. https://doi.org/10.1111/j.1467-6486.2011.01030.x

Boyd, B., \& Hollensen, S. (2012). Strategic management of a family-owned airline: Analysing the absorptive capacity of Cimber Sterling Group A/S. Journal of Family Business Strategy, 3(2), 70-78. https://doi.org/10.1016/j.jfbs.2012.03.003

Bozzi, S., Barontini, R., \& Miroshnychenko, I. (2017). Investor protection and CEO compensation in family firms. Corporate Ownership and Control, 14(2), 17-29. https://doi.org/10.22495/cocv14i2art2

Block, A. J., Opsahl, T., George, G., \& Gann, D. M. (2012). The Effects of Culture and Structure on Strategic Flexibility during Business Model Innovation. Journal of Management Studies, 49, 279-305. https://doi.org/10.1111/j.1467-6486.2011.01030.x

Brozovic, D. (2018). Strategic flexibility: A review of the literature. International Journal of Management Reviews, 20(1), 3-31. https://doi.org/10.1111/ijmr.12111

Burchell, B., \& Marsh, C. (1992). The effect of questionnaire length on survey response. Quality and Quantity, 26(3), 233-244. https://doi.org/10.1007/bf00172427

Cepeda-Carrion, G., Cegarra-Navarro, J. G., \& Jimenez-Jimenez, D. (2012). The effect of absorptive capacity on innovativeness: Context and information systems capability as catalysts. British Journal of Management, 23(1), 110-129. https://doi.org/10.1111/j.14678551.2010.00725.x

Chin, W. W. (1998). The partial least squares approach for structural equation modeling. In G. A. Marcoulides (Ed.), Methodology for business and management (pp. 295-336). Mahwah, NJ: Lawrence Erlbaum Associates Inc. 
Chirico, F., \& Salvato, C. (2008). Knowledge integration and dynamic organizational adaptation in family firms. Family Business Review, 21(2), 169-181. https://doi.org/10.1111/j.17416248.2008.00117.x

Classen, N., Carree, M., Van Gils, A., \& Peters, B. (2013). Innovation in family and non-family SMEs: An exploratory analysis. Small Business Economics, 42(3), 595-609. https://doi.org/10.1007/s11187-013-9490-z

Clauss, T. (2017). Measuring business model innovation: Conceptualization, scale development, and proof of performance. $R \& D$ Management, 47(3), 385-403. https://doi.org/10.1111/radm.12186

Clauss, T., Abebe, M., Tangpong, C., \& Hock, M. (2019). Strategic agility, business model innovation, and firm performance: An empirical investigation. IEEE Transactions on Engineering Management, 1-18. https://doi.org/10.1109/TEM.2019.2910381

Cohen, W. M., \& Levinthal, D. A. (1990). Absorptive capacity: A new perspective on learning and innovation. Administrative Science Quarterly, 35(1), 128-152. https://doi.org/10.2307/2393553

Crespo, D. C. (2015). Commission recognises SMEs as 'driving force' of EU economy. The Parliament Magazine. https://www.theparliamentmagazine.eu/articles/feature/commissionrecognises-smes-driving-force-eu-economy/ Accessed 6 February 2020.

Cucculelli, M., \& Bettinelli, C. (2015). Business models, intangibles and firm performance: Evidence on corporate entrepreneurship from Italian manufacturing SMEs. Small Business Economics, 45(2), 329-350. https://doi.org/10.1007/s11187-015-9631-7 
Damanpour, F. (1996). Organizational complexity and innovation: Developing and testing multiple contingency models. Management Science, 42(5), 693-716. https://doi.org/10.1287/mnsc.42.5.693

Davies, A., \& Brady, T. (2000). Organisational capabilities and learning in complex product systems: Towards repeatable solutions. Research Policy, 29(7), 931-953. https://doi.org/10.1016/S0048-7333(00)00113-X

Dean, T. J., Brown, R. L., \& Bamford, C. E. (1998). Differences in large and small firm responses to environmental context: Strategic implications from a comparative analysis of business formations. Strategic Management Journal, 19(8), 709-728. https://doi.org/10.1002/(sici)1097-0266(199808)19:8<709::aid-smj966>3.0.co;2-9

De Massis, A., Frattini, F., Kotlar, J., Petruzzelli, A. M., \& Wright, M. (2016). Innovation through tradition: Lessons from innovative family businesses and directions for future research. Academy of Management Perspectives, 30(1), 93-116. https://doi.org/10.5465/amp.2015.0017

De Massis, A., Frattini, F., Majocchi, A., \& Piscitello, L. (2017). Family firms in the global economy: Toward a deeper understanding of internationalization determinants, processes, and outcomes. Global Strategy Journal, 8(1), 3-21. https://doi.org/10.1002/gsj.1199

De Massis, A., \& Kotlar, J. (2014). The case study method in family business research: Guidelines for qualitative scholarship. Journal of Family Business Strategy, 5(1), 15-29. https://doi.org/10.1016/j.jfbs.2014.01.007

De Massis, A., Kotlar, J., Campopiano, G., \& Cassia, L. (2013). Dispersion of family ownership and the performance of small-to-medium size private family firms. Journal of Family Business Strategy, 4(3), 166-175. https://doi.org/10.1016/j.jfbs.2013.05.001 
De Massis, A., Sharma, P., Chua, J. H., \& Chrisman, J. J. (2012). Family business studies: An annotated bibliography. Cheltenham: Edward Elgar Publishing.

Domínguez-CC, M., \& Barroso-Castro, C. (2016). Managerial change and strategic change: The temporal sequence. Journal of Management \& Organization, 23(1), 46-73. https://doi.org/10.1017/jmo.2016.49

Dosi, G., Nelson, R. R., \& Winter, S. G. (2001). The nature and dynamics of organizational capabilities. Oxford. https://doi.org/10.1093/0199248540.001.0001

Doz, Y., \& Kosonen, M. (2008). Fast strategy: How strategic agility will help you stay ahead of the game. Harlow: Pearson Education Limited.

Eisenhardt, K. M., \& Martin, J. A. (2000). Dynamic capabilities: What are they? Strategic Management Journal, 21(10/11), 1105-1121. https://doi.org/10.1002/10970266(200010/11)21:10/11<1105::AID-SMJ133>3.0.CO;2-E

Fan, Z., Wu, D., \& Wu, X. (2013). Proactive and reactive strategic flexibility in coping with environmental change in innovation. Asian Journal of Technology Innovation, 21(2), 187-201. https://doi.org/10.1080/19761597.2013.866316

Flatten, T. C., Engelen, A., Zahra, S. A., \& Brettel, M. (2011). A measure of absorptive capacity: Scale development and validation. European Management Journal, 29(2), 98-116. https://doi.org/10.1016/j.emj.2010.11.002

Fornell, C., \& Larcker, D. F. (1981). Evaluating structural equation models with unobservable variables and measurement error. Journal of Marketing Research, 18(1), 39-50. https://doi.org/10.1177/002224378101800104

Foss, N. J., \& Saebi, T. (2017). Fifteen years of research on business model innovation. Journal of Management, 43(1), 200-227. https://doi.org/10.1177/0149206316675927 
Foss, N. J., \& Saebi, T. (2018). Business models and business model innovation: Between wicked and paradigmatic problems. Long Range Planning, 51(1), 9-21. https://doi.org/10.1016/j.1rp.2017.07.006

Frankerberger, A., Weiblen, T., Csik, M., \& Gassmann, O. (2013). The 4I-framework of business model innovation: A structured view on process phases and challenges. International Journal of Product Development, 18, 249-273. https://doi.org/10.1504/IJPD.2013.055012

Grewal, R., \& Tansuhaj, P. (2001). Building organizational capabilities for managing economic crisis: The role of market orientation and strategic flexibility. Journal of Marketing, 65(2), 6780. https://doi.org/10.1509/jmkg.65.2.67.18259

Grundström, C., Öberg, C., \& Rönnbäck, A. Ö. (2012). Family-owned manufacturing SMEs and innovativeness: A comparison between within-family successions and external takeovers. Journal of Family Business Strategy, 3(3), 162-173. https://doi.org/10.1016/j.jfbs.2012.07.001

Hair, J. F., Hult, G. T. M., Ringle, C. M., \& Sarstedt, M. (2014). A primer on partial least squares structural equation modeling (PLS-SEM). Thousand Oaks: SAGE Publications.

Hair, J. F., Sarstedt, M., Ringle, C. M., \& Mena, J. A. (2012). An assessment of the use of partial least squares structural equation modeling in marketing research. Journal of the Academy of Marketing Science, 40(3), 414-433. https://doi.org/10.1007/s11747-011-0261-6

Henseler, J., Ringle, C. M., \& Sinkovics, R. R. (2009). The use of partial least squares path modeling in international marketing. In R. R. Sinkovics \& P. N. Ghauri (Eds.), New challenges to international marketing (pp. 277-319). Bingley: Emerald Group Publishing Limited. 
Hitt, M. A., Keats, B. W., \& DeMarie, S. M. (1998). Navigating in the new competitive landscape: Building strategic flexibility and competitive advantage in the 21 st century. Academy of Management Perspectives, 12(4), 22-42.

https://doi.org/10.5465/ame.1998.1333922

Howorth, C., \& Moro, A. (2012). Trustworthiness and interest rates: An empirical study of Italian SMEs. Small Business Economics, 39(1), 161-177. https://doi.org/10.1007/s11187-010-92854

IBM Global Business Services (2006). Expanding the innovation horizon: The Global CEO study. http://www.businessmodelinnovation.org.sg/wpcontent/uploads/2015/01/global_ceo_study.pdf Accessed 6 February 2020

Jansen, J. J. P., Van Den Bosch, F. A. J., \& Volberda, H. W. (2005). Managing potential and realized absorptive capacity: How do organizational antecedents matter? Academy of Management Journal, 48(6), 999-1015. https://doi.org/10.5465/amj.2005.19573106

Johnson, J. L., Lee, R. P.-W., Saini, A., \& Grohmann, B. (2003). Market-focused strategic flexibility: Conceptual advances and an integrative model. Journal of the Academy of Marketing Science, 31(1), 74-89. https://doi.org/10.1177/0092070302238603

Johnson, M. V., Christensen, C. M., \& Kagermann, H. (2008). Reinventing your business model. Harvard Business Review, 86(12), 50-59. https://hbr.org/2008/12/reinventing-your-businessmodel

Kandemir, D., \& Acur, N. (2012). Examining proactive strategic decision-making flexibility in new product development. Journal of Product Innovation Management, 29(4), 608-622. https://doi.org/10.1111/j.1540-5885.2012.00928.x 
Kastalli, I. V., \& Van Looy, B. (2013) Servitization: Disentangling the impact of service business model innovation on manufacturing firm performance. Journal of Operations Management, 31(4), 169-180. https://doi.org/10.1016/j.jom.2013.02.001

Kellermanns, F. W., Eddleston, K. A., Sarathy, R., \& Murphy, F. (2012). Innovativeness in family firms: A family influence perspective. Small Business Economics, 38(1), 85-101. https://doi.org/10.1007/s11187-010-9268-5

Khan, Z., Lew, Y. K., \& Marinova, S. (2019). Exploitative and exploratory innovations in emerging economies: The role of realized absorptive capacity and learning intent. International Business Review, 28(3), 499-512. https://doi.org/10.1016/j.ibusrev.2018.11.007

Khanagha, S., Volberda, H., \& Oshri, I. (2014). Business model renewal and ambidexterity: Structural alteration and strategy formation process during transition to a Cloud business model. $R \& D$ Management, 44(3), 322-340. https://doi.org/10.1111/radm.12070

Kostopoulos, K., Papalexandris, A., Papachroni, M., \& Ioannou, G. (2011). Absorptive capacity, innovation, and financial performance. Journal of Business Research, 64(12), 1335-1343. https://doi.org/10.1016/j.jbusres.2010.12.005

Kotlar, J., De Massis, A., Frattini, F., \& Kammerlander, N. (2020). Motivation gaps and implementation traps: The paradoxical and time-varying effects of family ownership on firm absorptive capacity. Journal of Product Innovation Management, 37(1), 2-25. https://doi.org/10.1111/jpim.12503

Leal-Rodríguez, A. L., Ariza-Montes, J. A., Roldán, J. L., \& Leal-Millán, A. G. (2014). Absorptive capacity, innovation and cultural barriers: A conditional mediation model. Journal of Business Research, 67(5), 763-768. https://doi.org/10.1016/j.jbusres.2013.11.041 
Liang, H., Saraf, N., Hu, Q., \& Xue, Y. (2007). Assimilation of enterprise systems: the effect of institutional pressures and the mediating role of top management. MIS Quarterly, 31(1), 5987. https://doi.org/10.2307/25148781

Liao, J., Welsch, H., \& Stoica, M. (2003). Organizational absorptive capacity and responsiveness: An empirical investigation of growth-oriented SMEs. Entrepreneurship Theory and Practice, 28(1), 63-86. https://doi.org/10.1111/1540-8520.00032

Limaj, E., \& Bernroider, E. W. N. (2019). The roles of absorptive capacity and cultural balance for exploratory and exploitative innovation in SMEs. Journal of Business Research, 94, 137153. https://doi.org/10.1016/j.jbusres.2017.10.052

Liu, H., Jiang, X., Zhang, J., \& Zhao, X. (2013). Strategic flexibility and international venturing by emerging market firms: The Moderating effects of institutional and relational factors. Journal of International Marketing, 21(2), 79-98. https://doi.org/10.1509/jim.12.0047

Lucchese, M., Nascia, L., \& Pianta, M. (2016). Industrial policy and technology in Italy. Economia e Politica Industriale, 43(3), 233-260. https://doi.org/10.1007/s40812-016-0047-4

MacKinnon, D. P., Lockwood, C. M., Hoffman, J. M., West, S. G., \& Sheets, V. (2002). A comparison of methods to test mediation and other intervening variable effects. Psychological Methods, 7(1), 83-104. https://doi.org/10.1037/1082-989x.7.1.83

Makkonen, H., Pohjola, M., Olkkonen, R., \& Koponen, A. (2014). Dynamic capabilities and firm performance in a financial crisis. Journal of Business Research, 67(1), 2707--2719. https://doi.org/10.1016/j.jbusres.2013.03.020

Massa, S., \& Testa, S. (2008). Innovation and SMEs: Misaligned perspectives and goals among entrepreneurs, academics, and policy makers. Technovation, 28(7), 393-407. https://doi.org/10.1016/j.technovation.2008.01.002 
Matzler, K., Veider, V., Hautz, J., \& Stadler, C. (2015). The impact of family ownership, management, and governance on innovation. Journal of Product Innovation Management, 32(3), 319-333. https://doi.org/10.1111/jpim.12202

Medina, C. C., Lavado, A. C., \& Cabrera, R. V. (2006). Identifying the variables associated with types of innovation, radical or incremental: Strategic flexibility, organisation and context.

International Journal of Technology Management, 35(1/2/3/4).

https://doi.org/10.1504/ijtm.2006.009230

Miller, D., \& Friesen, P. H. (1984). A longitudinal study of the corporate life cycle. Management Science, 30(10), 1161-1183. https://doi.org/10.1287/mnsc.30.10.1161

Miller, D., \& Dröge, C. (1986). Psychological and traditional determinants of structure. Administrative Science Quarterly, 31(4), 539-560. https://doi.org/10.2307/2392963

Muller, P., Julius, J., Herr, D., Koch, L., Peycheva, V., \& McKiernan, S. (2017). Annual report on European SMEs 2016/2017. Retrieved from https://www.smeacademy.eu/uploads/5/2/4/2/52422965/171217_annual_report__eu_smes_2016-2017.pdf

Nadkarni, S., \& Herrmann, P. O. L. (2010). CEO personality, strategic flexibility, and firm performance: The case of the Indian business process outsourcing industry. Academy of Management Journal, 53(5), 1050-1073. https://doi.org/10.5465/amj.2010.54533196

Nylén, D., \& Holmström, J. (2015). Digital innovation strategy: A framework for diagnosing and improving digital product and service innovation. Business Horizons, 58(1), 57-67. https://doi.org/10.1016/j.bushor.2014.09.001

O'Brien, R. M. (2007). A caution regarding rules of thumb for variance inflation factors. Quality \& Quantity, 41(5), 673-690. https://doi.org/10.1007/s11135-006-9018-6 
Perrini, F. (2006). SMEs and CSR theory: Evidence and implications from an Italian Perspective. Journal of Business Ethics, 67(3), 305-316. https://doi.org/10.1007/s10551-006-9186-2

Podsakoff, P. M., MacKenzie, S. B., Lee, J.-Y., \& Podsakoff, N. P. (2003). Common method biases in behavioral research: A critical review of the literature and recommended remedies. Journal of Applied Psychology, 88(5), 879-903. https://doi.org/10.1037/0021-9010.88.5.879

Ringle, C. M., Sarstedt, M., \& Straub, D. W. (2012). Editor's comments: A critical look at the use of PLS-SEM in MIS Quarterly. MIS Quarterly, 36(1), iii-xiv. https://doi.org/10.2307/41410402

Ringle, C. M., Wende, S., \& Becker, J.-M. (2015). SmartPLS3. Boenningstedt: SmartPLS GmbH. Retrieved from http://www.smartpls.com

Russo, A., \& Perrini, F. (2010). Investigating stakeholder theory and social capital: CSR in large firms and SMEs. Journal of Business Ethics, 91(2), 207-221. https://doi.org/10.1007/s10551009-0079-z

Sanchez, R. (1995). Strategic flexibility in product competition. Strategic Management Journal, 16(S1), 135-159. https://doi.org/10.1002/smj.4250160921

Sanchez, R., \& Mahoney, J. T. (1996). Modularity, flexibility, and knowledge management in product and organization design. Strategic Management Journal, 17(S2), 63-76. https://doi.org/10.1002/smj.4250171107

Sarstedt, M., Hair, J. F., Cheah, J.-H., Becker, J.-M., \& Ringle, C. M. (2019). How to specify, estimate, and validate higher-order constructs in PLS-SEM. Australasian Marketing Journal 27(3), 197-211. https://doi.org/10.1016/j.ausmj.2019.05.003 
Schneider, S., \& Spieth, P. (2013). Business model innovation: Towards an integrated future research agenda. International Journal of Innovation Management, 17(1), 1340001. https://doi.org/10.1142/S136391961340001X

Schneider, S., \& Spieth, P. (2014). Business model innovation and strategic flexibility: Insights from an experimental research design. International Journal of Innovation Management, 18(06), 1440009. https://doi.org/10.1142/S136391961440009X

Spieth, P., Schneckenberg, D., \& Ricart, J. E. (2014). Business model innovation - state of the art and future challenges for the field. $R \& D$ Management, 44(3), 237-247. https://doi.org/10.1111/radm.12071

Spieth, P., Schneckenberg, D., \& Matzler, K. (2016). Exploring the linkage between business model (\&) innovation and the strategy of the firm. R\&D Management, 46(3), 403-413. https://doi.org/10.1111/radm.12218

Spieth, P., \& Schneider, S. (2016). Business model innovativeness: Designing a formative measure for business model innovation. Journal of Business Economics, 86(6), 671-696. https://doi.org/10.1007/s11573-015-0794-0

Strobl, A., Matzler, K., Nketia, B. A., \& Veider, V. (2018). Individual innovation behavior and firm-level exploration and exploitation: how family firms make the most of their managers. Review of Managerial Science, 1-36. https://doi.org/10.1007/s11846-018-0309-9

Sun, P. Y. T., \& Anderson, M. H. (2011). The combined influence of top and middle management leadership styles on absorptive capacity. Management Learning, 43(1), 25-51. https://doi.org/10.1177/1350507611405116

Tabachnick, B. G., \& Fidell, L. S. (2012). Using multivariate statistics (6 ed.). Boston: Pearson Education. 
Teece, D. J. (2010). Business models, business strategy and innovation. Long Range Planning, 43(2), 172-194. https://doi.org/10.1016/j.lrp.2009.07.003

Todorova, G., \& Durisin, B. (2007). Absorptive capacity: Valuing a reconceptualization. Academy of Management Review, 32(3), 774-786. https://doi.org/10.2307/20159334

Vermuelen, F. (2018). The first step of business model innovation: Focus. Forbes. https://www.forbes.com/sites/freekvermeulen/2018/01/11/the-first-step-of-business-modelinnovation-focus/\#1e66e4965022 Accessed 6 February 2020

Volberda, H. W., Foss, N. J., \& Lyles, M. A. (2010). Absorbing the concept of absorptive capacity: How to realize its potential in the organization field. Organization Science, 21(4), 931-951. https://doi.org/10.1287/orsc.1090.0503

Williams, L. J., Edwards, J. R., \& Vandenberg, R. J. (2003). Recent advances in causal modeling methods for organizational and management research. Journal of Management, 29(6), 903936. https://doi.org/10.1016/s0149-2063_03_00084-9

Worren, N., Moore, K., \& Cardona, P. (2002). Modularity, strategic flexibility, and firm performance: a study of the home appliance industry. Strategic Management Journal, 23(12), 1123-1140. https://doi.org/10.1002/smj.276

Zahra, S. A., \& George, G. (2002). Absorptive capacity: A review, reconceptualization, and extension. Academy of Management Review, 27(2), 185-203. https://doi.org/ $10.5465 / \mathrm{amr} .2002 .6587995$

Zahra, S. A., Hayton, J. C., Neubaum, D. O., Dibrell, C., \& Craig, J. (2008). Culture of family commitment and strategic flexibility: The moderating effect of stewardship. Entrepreneurship Theory and Practice, 32(6), 1035-1054. https://doi.org/10.1111/j.1540-6520.2008.00271.x 
Zhao, X., Lynch, J. G., \& Chen, Q. (2010). Reconsidering Baron and Kenny: Myths and truths about mediation analysis. Journal of Consumer Research, 37(2), 197-206. https://doi.org/10.1086/651257

Zhou, K. Z., \& Wu, F. (2010). Technological capability, strategic flexibility, and product innovation. Strategic Management Journal, 31(5), 547-561. https://doi.org/10.1002/smj.830

Zott, C., \& Amit, R. (2007). Business model design and the performance of entrepreneurial firms. Organization Science, 18(2), 181-199. https://doi.org/10.1287/orsc.1060.0232

Zott, C., \& Amit, R. (2008). The fit between product market strategy and business model: Implications for firm performance. Strategic Management Journal, 29(1), 1-26. https://doi.org/10.1002/smj.642

Zott, C., \& Amit, R. (2010). Business model design: An activity system perspective. Long Range Planning, 43(2), 216-226. https://doi.org/10.1016/j.lrp.2009.07.004

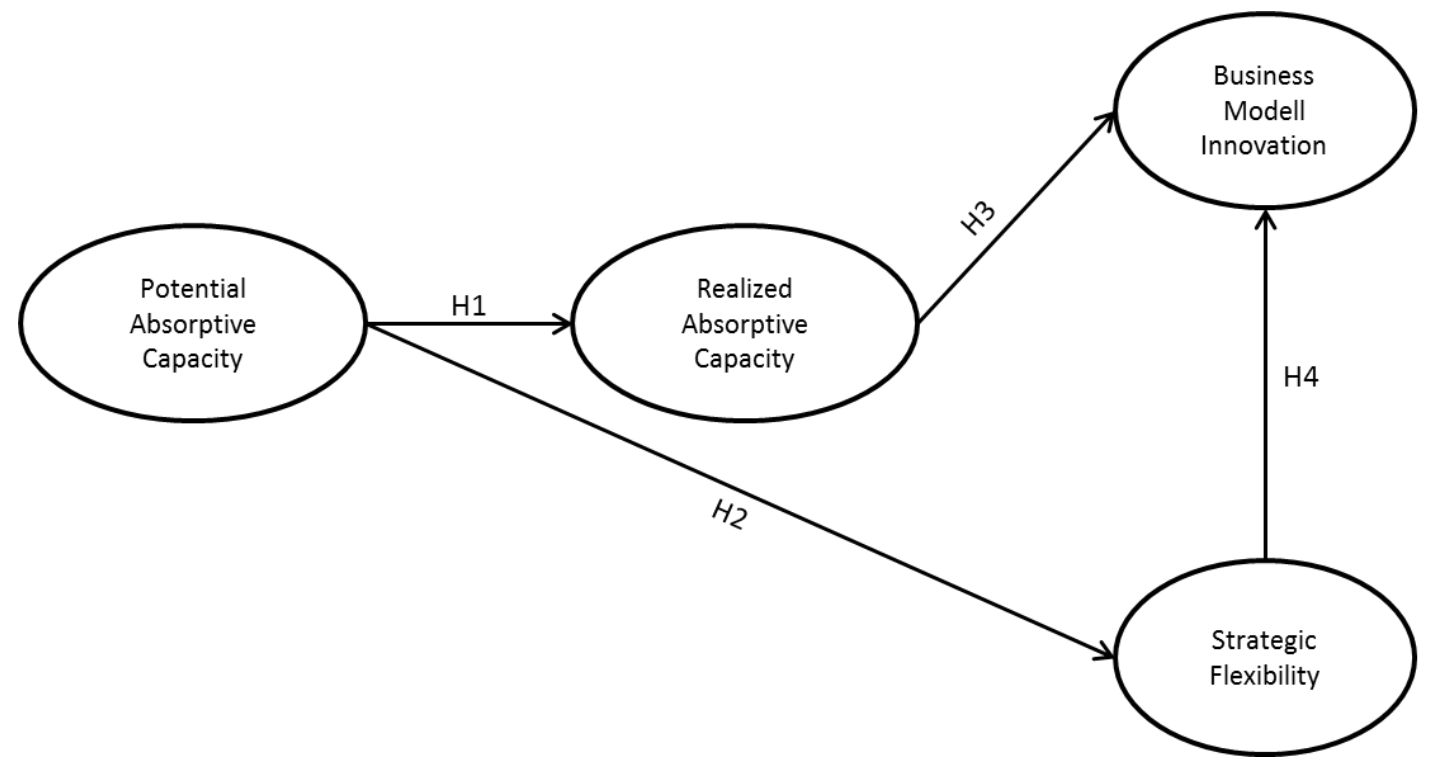

Figure 1: Hypothesized Model 


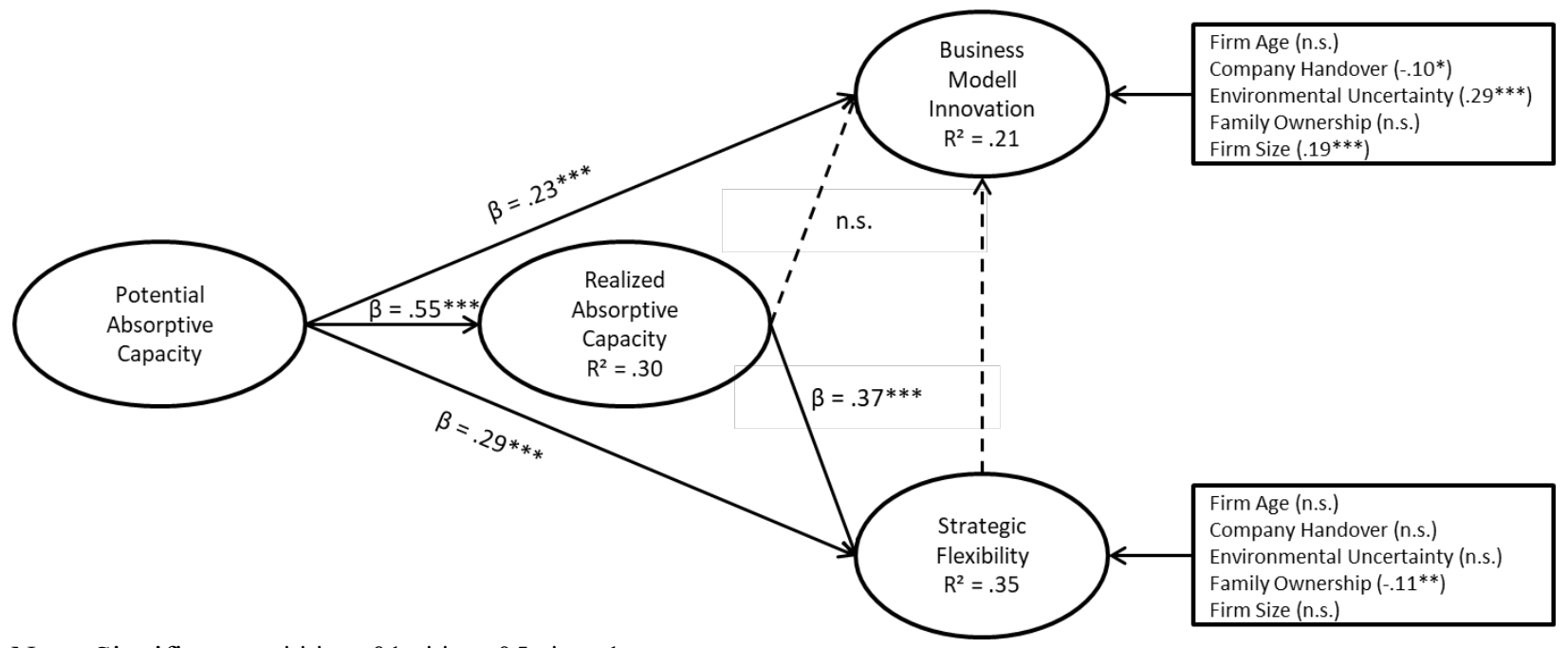

Note: Significant at ${ }^{* * *} \mathrm{p}<.01,{ }^{* *} \mathrm{p}<.05,{ }^{*} \mathrm{p}<.1$;

Figure 2: Results Model 3

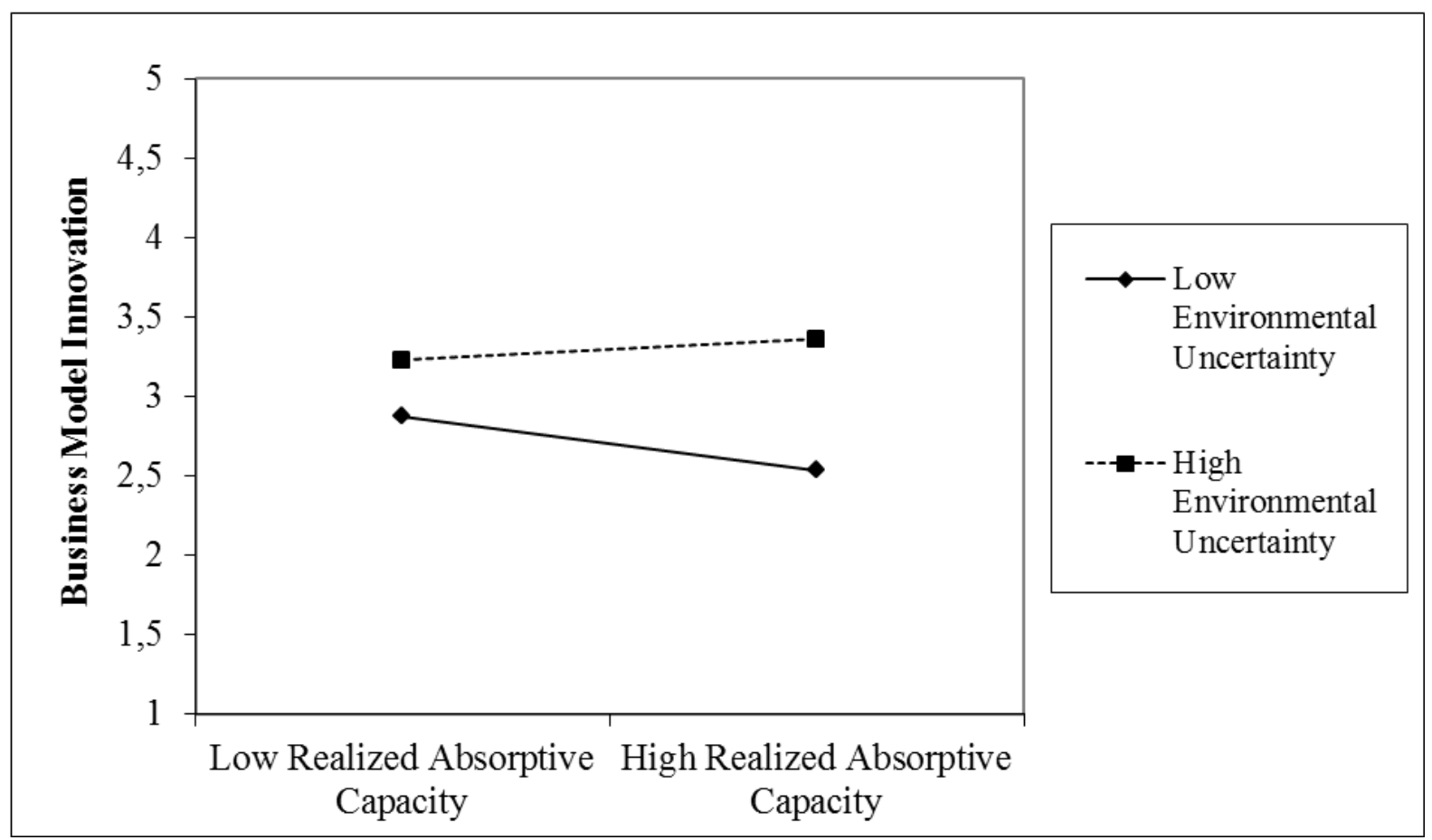

Figure 3: The Moderating Effect of Environmental Uncertainty on the Relationship between

Realized Absorptive Capacity and BMI 
Potential Absorptive Capacity

Knowledge Acquisition $(C R=.87 ; A V E=.77)$

The search for relevant information concerning our industry is every-day business in our company

Our management motivates the employees to use information sources within our industry

Knowledge Assimilation $(C R=.92 ; A V E=.75)$

In our company ideas and concepts are communicated cross-departmental

Our management emphasizes cross-departmental support to solve problems

In our company there is a quick information flow, e.g., if a business unit obtains important information it communicates this information promptly to all other business units or departments

Our management demands periodical cross-departmental meetings to interchange new developments, problems, and achievements

Realized Absorptive Capacity

Knowledge Exploitation $(C R=.88 ; A V E=.70)$

Our management supports the development of prototypes

Our company regularly reconsiders technologies and adapts them accordant to new knowledge

Our company has the ability to work more effective by adopting new technologies

Knowledge Transformation $(C R=.94 ; A V E=.81)$

Our employees have the ability to structure and to use collected knowledge

Our employees are used to absorb new knowledge as well as to prepare it for further purposes and to make it available

Our employees successfully link existing knowledge with new insights

Our employees are able to apply new knowledge in their practical work

Strategic Flexibility $(C R=.94 ; A V E=.71)$

If circumstances change, our organization can easily change its current plans

If circumstances change, our organization is prepared to react in a modified and viable manner

If circumstances change, our organization can control a shift in strategy

If circumstances change, our organization has the necessary practical knowledge to make shifts in daily routines and practices

If circumstances change, our organization can pro-actively develop a new project

If circumstances change, our organization can shift projects with a high probability of success

Table 1: Psychometric Properties of the Reflective Scales 


\begin{tabular}{lccc}
\hline Construct / Item & Weight & T-statistic & VIF \\
\hline Revenue Model Innovation & & & \\
Revenue mechanisms have changed & $.64^{* * *}$ & 10.12 & 1.23 \\
Cost mechanisms have changed & $.54^{* * *}$ & 7.69 & 1.23 \\
Value Architecture Innovation & & & \\
The firm's core competences and resources have changed & $.21^{* * *}$ & 2.95 & 1.45 \\
Internal value creation activities have changed & $.35^{* * *}$ & 4.86 & 1.51 \\
Roles and involvement of partners in the value creation & $.30^{* * *}$ & 4.09 & 1.43 \\
process have changed & $.46^{* * *}$ & 7.76 & 1.30 \\
1646Distribution has changed & & & \\
Value Offering Innovation & $.36^{* * *}$ & 5.38 & 1.38 \\
Target customers have changed & $.51^{* * *}$ & 8.69 & 1.33 \\
The product and service offering has changed & $.38^{* * *}$ & 5.33 & 1.57 \\
The firm's positioning in the market has changed & &
\end{tabular}

Note: Significant at ${ }^{* * *} \mathrm{p}<.01,{ }^{*} \mathrm{p}<<.05,{ }^{*} \mathrm{p}<.1$

Table 2: Weights, T-statistics and VIFs for Lower Order Formative Constructs

\begin{tabular}{lccc}
\hline Construct & Weight & T-statistic & VIF \\
\hline BMI & & & \\
Revenue Model Innovation & $.27^{* * *}$ & 26.00 & 2.07 \\
Value Architecture Innovation & $.48^{* * *}$ & 54.68 & 2.71 \\
Value Offering Innovation & $.37^{* * *}$ & 33.34 & 2.44 \\
Potential Absorptive Capacity & & & \\
Knowledge Acquisition & $.50^{* * *}$ & 6.19 & 1.12 \\
Knowledge Assimilation & $.72^{* * *}$ & 10.04 & 1.12 \\
Realized Absorptive Capacity & & & \\
Knowledge Exploitation & $.48^{* * *}$ & 4.23 & 1.51 \\
Knowledge Transformation & $.66^{* * *}$ & 6.48 & 1.36 \\
\hline
\end{tabular}

Note: Significant at ${ }^{* * *} \mathrm{p}<.01,{ }^{* *} \mathrm{p}<.05,{ }^{*} \mathrm{p}<.1$

Table 3: Weights, T-statistics and VIFs for Higher Order Constructs 


\begin{tabular}{|c|c|c|c|c|c|c|c|c|c|c|c|c|c|}
\hline & (1) & (2) & (3) & (4) & (5) & (6) & (7) & (8) & (9) & (10) & (11) & (12) & (13) \\
\hline Firm Age (1) & 1 & & & & & & & & & & & & \\
\hline Company Handover (2) & .04 & 1 & & & & & & & & & & & \\
\hline Environmental Uncertainty (3) & -.07 & -.02 & 1 & & & & & & & & & & \\
\hline Family Ownership (4) & $.18 * * *$ & -.08 & -.04 & 1 & & & & & & & & & \\
\hline Knowledge Acquisition (5) & .03 & -.06 & .08 & .01 & .88 & & & & & & & & \\
\hline Knowledge Assimilation (6) & .04 & -.02 & .02 & $-.17 * * *$ & $.33 * * *$ & .87 & & & & & & & \\
\hline Knowledge Exploitation (7) & .08 & .05 & $.27 * * *$ & -.02 & $.38 * * *$ & $.45 * * *$ & .84 & & & & & & \\
\hline Knowledge Transformation (8) & .00 & -.01 & .10 & -.08 & $.33 * * *$ & $.37 * * *$ & $.47 * * *$ & .90 & & & & & \\
\hline Firm Size (9) & $.23 * * *$ & .03 & .03 & $-.18 * * *$ & $.13 * *$ & $.14 * *$ & $.21 * * *$ & -.03 & 1 & & & & \\
\hline Revenue Model Innovation (10) & -.05 & $-.18 * * *$ & $.13 * *$ & -.05 & .04 & $.12^{*}$ & .05 & .03 & .08 & n.a. & & & \\
\hline Strategic Flexibility (11) & .02 & .03 & .06 & $-.17 * * *$ & $.36 * * *$ & $.44 * * *$ & $.41 * * *$ & $.49 * * *$ & $.10^{*}$ & .02 & .85 & & \\
\hline Value Architecture Innovation (12) & -.02 & $-.15 * *$ & $.29 * * *$ & -.07 & $.17 * * *$ & $.26 * * *$ & $.19 * * *$ & $.10^{*}$ & $.20 * * *$ & $.66 * * *$ & $.15 * * *$ & n.a. & \\
\hline Value Offering Innovation (13) & -.02 & $-.16 * * *$ & $.25 * * *$ & -.04 & $.20 * * *$ & $.15 * *$ & $.17 * * *$ & .08 & $.17 * * *$ & $.65 * * *$ & $.12 * *$ & $.73 * * *$ & n.a. \\
\hline
\end{tabular}

Note: Square root of AVE in italics on the diagonal; Significant at $* * * \mathrm{p}<.01, * * \mathrm{p}<.05, * \mathrm{p}<.1 ;$ n.a. $=$ not applicable due to formative measurement specification;

Table 4: Discriminant Validity Analysis First Order Constructs

\begin{tabular}{|c|c|c|c|c|c|c|c|c|c|}
\hline & (1) & (2) & (3) & (4) & (5) & (6) & (7) & (8) & (9) \\
\hline BMI (1) & 1 & & & & & & & & \\
\hline Firm Age (2) & -.03 & 1 & & & & & & & \\
\hline Company Handover (3) & $-.18 * * *$ & .04 & 1 & & & & & & \\
\hline Environmental Uncertainty (4) & $.27 * * *$ & -.07 & -.02 & 1 & & & & & \\
\hline Family Ownership (5) & -.06 & $.18 * * *$ & -.08 & -.04 & 1 & & & & \\
\hline Potential Absorptive Capacity (6) & $.23 * * *$ & .05 & -.04 & .06 & $-.12 * *$ & 1 & & & \\
\hline Realized Absorptive Capacity (7) & $.14 * *$ & .03 & .02 & $.19 * * *$ & -.08 & $.55 * * *$ & 1 & & \\
\hline Firm Size (8) & $.18 * * *$ & $.23 * * *$ & .03 & .03 & $-.18 * * *$ & $.17 * * *$ & .08 & 1 & \\
\hline Strategic Flexibility (9) & $.13 * *$ & -.02 & .03 & .06 & $-.17 * * *$ & $.50 * * *$ & $.55 * * *$ & $.10 *$ & 1 \\
\hline
\end{tabular}

Note: Significant at $* * * \mathrm{p}<.01, * * \mathrm{p}<.05, * \mathrm{p}<.1$

Table 5: Latent Variable Correlations Structural Model 


\begin{tabular}{|c|c|c|c|c|c|c|c|c|c|}
\hline & & & Model 1 & & & & Model 2 & & \\
\hline & Path & Estimate & T-Statistics & $\mathbf{f}^{2}$ & VIF & Estimate & T-Statistics & $f^{2}$ & VIF \\
\hline \multirow{6}{*}{ 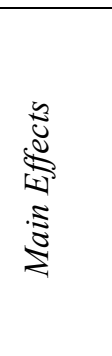 } & $\mathrm{SF} \rightarrow \mathrm{BMI}$ & & & & & $.12 *$ & 1.86 & .01 & 1.38 \\
\hline & $\mathrm{PAC} \rightarrow \mathrm{BMI}$ & & & & & & & & \\
\hline & $\mathrm{RAC} \rightarrow \mathrm{BMI}$ & & & & & .06 & .88 & .00 & 1.45 \\
\hline & $\mathrm{PAC} \rightarrow \mathrm{SF}$ & & & & & $.48^{* * *}$ & 8.95 & .31 & 1.04 \\
\hline & $\mathrm{RAC} \rightarrow \mathrm{SF}$ & & & & & & & & \\
\hline & $\mathrm{PAC} \rightarrow \mathrm{RAC}$ & & & & & $.55^{* * *}$ & 11.33 & .43 & 1.00 \\
\hline \multirow{4}{*}{ 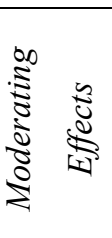 } & $\mathrm{PAC} * \mathrm{EU} \rightarrow \mathrm{BMI}$ & & & & & & & & \\
\hline & $\mathrm{RAC} * \mathrm{EU} \rightarrow \mathrm{BMI}$ & & & & & & & & \\
\hline & $\mathrm{PAC} * \mathrm{EU} \rightarrow \mathrm{SF}$ & & & & & & & & \\
\hline & $\mathrm{RAC} * \mathrm{EU} \rightarrow \mathrm{SF}$ & & & & & & & & \\
\hline \multirow{10}{*}{$\begin{array}{l}\tilde{0} \\
\vdots \\
\vdots \\
0\end{array}$} & $\mathrm{FA} \rightarrow \mathrm{BMI}$ & -.03 & .55 & .00 & 1.12 & -.03 & .51 & .00 & 1.13 \\
\hline & $\mathrm{CH} \rightarrow \mathrm{BMI}$ & $-.14 * *$ & 2.04 & .02 & 1.01 & $-.12 * *$ & 1.98 & .02 & 1.01 \\
\hline & $\mathrm{EU} \rightarrow \mathrm{BMI}$ & $.30 * * *$ & 4.97 & .10 & 1.01 & $.28 * * *$ & 4.92 & .09 & 1.08 \\
\hline & $\mathrm{FO} \rightarrow \mathrm{BMI}$ & -.01 & .21 & .00 & 1.10 & .01 & .21 & .00 & 1.12 \\
\hline & $\mathrm{FS} \rightarrow \mathrm{BMI}$ & $.22 * * *$ & 3.49 & .05 & 1.11 & $.21 * * *$ & 3.34 & .05 & 1.13 \\
\hline & $\mathrm{FA} \rightarrow \mathrm{SF}$ & -.01 & .20 & .00 & 1.12 & -.03 & .58 & .00 & 1.12 \\
\hline & $\mathrm{CH} \rightarrow \mathrm{SF}$ & .02 & .30 & .00 & 1.01 & .05 & .76 & .00 & 1.01 \\
\hline & $\mathrm{EU} \rightarrow \mathrm{SF}$ & .05 & .79 & .00 & 1.01 & .03 & .53 & .00 & 1.01 \\
\hline & $\mathrm{FO} \rightarrow \mathrm{SF}$ & $-.15 * *$ & 2.37 & .02 & 1.10 & $-.10 *$ & 1.78 & .01 & 1.11 \\
\hline & $\mathrm{FS} \rightarrow \mathrm{SF}$ & .08 & 1.18 & .01 & 1.11 & .01 & .20 & .00 & 1.13 \\
\hline \multirow{6}{*}{ 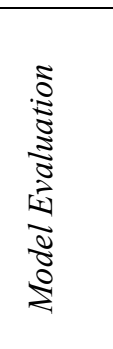 } & $\mathrm{R}^{2} \mathrm{BMI}$ & & .16 & & & & .18 & & \\
\hline & $\mathrm{R}^{2}$ adjusted $\mathrm{BMI}$ & & .14 & & & & .16 & & \\
\hline & $\mathrm{R}^{2} \mathrm{SF}$ & & .04 & & & & .26 & & \\
\hline & $\mathrm{R}^{2}$ adjusted $\mathrm{SF}$ & & .02 & & & & .25 & & \\
\hline & $\mathrm{R}^{2} \mathrm{PAC}$ & & & & & & .30 & & \\
\hline & $\mathrm{R}^{2}$ adjusted $\mathrm{PAC}$ & & & & & & .30 & & \\
\hline
\end{tabular}

Note: Significant at ${ }^{* * *} \mathrm{p}<.01,{ }^{* *} \mathrm{p}<.05,{ }^{*} \mathrm{p}<.1 ; \mathrm{BMI}=$ Business Model Innovation; $\mathrm{SF}=$ Strategic Flexibility; PAC $=$ Potential Absorptive Capacity; RAC $=$ Potential Absorptive Capacity; EU = Environmental Uncertainty; FA = Firm Age; $\mathrm{CH}=$ Company Handover; FO = Family Ownership; FS = Firm Size; VIF = Variance Inflation Factor

Table 6: Results 


\begin{tabular}{|c|c|c|c|c|c|c|c|c|c|}
\hline & \multirow[b]{2}{*}{ Path } & \multicolumn{4}{|c|}{ Model 3} & \multicolumn{4}{|c|}{ Model 4} \\
\hline & & Estimate & T-Statistics & $\mathbf{f}^{2}$ & VIF & Estimate & T-Statistics & $\mathbf{f}^{2}$ & VIF \\
\hline \multirow{6}{*}{ 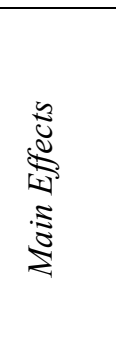 } & $\mathrm{SF} \rightarrow \mathrm{BMI}$ & .06 & .90 & .00 & 1.54 & .07 & 1.01 & .00 & 1.55 \\
\hline & $\mathrm{PAC} \rightarrow \mathrm{BMI}$ & $.23 * * *$ & 3.04 & .04 & 1.61 & $.24 * * *$ & 3.26 & .05 & 1.61 \\
\hline & $\mathrm{RAC} \rightarrow \mathrm{BMI}$ & -.04 & .53 & .00 & 1.72 & -.05 & .75 & .00 & 1.74 \\
\hline & $\mathrm{PAC} \rightarrow \mathrm{SF}$ & $.29 * * *$ & 4.57 & .09 & 1.48 & $.28 * * *$ & 4.43 & .08 & 1.49 \\
\hline & $\mathrm{RAC} \rightarrow \mathrm{SF}$ & $.37 * * *$ & 6.10 & .14 & 1.51 & $.37 * * *$ & 6.25 & .14 & 1.53 \\
\hline & $\mathrm{PAC} \rightarrow \mathrm{RAC}$ & $.55^{* * *}$ & 11.12 & .43 & 1.00 & $.55^{* * *}$ & 11.22 & .43 & 1.00 \\
\hline \multirow{4}{*}{ 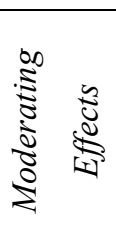 } & $\mathrm{PAC} * \mathrm{EU} \rightarrow \mathrm{BMI}$ & & & & & -.10 & 1.42 & .01 & 1.49 \\
\hline & $\mathrm{RAC} * \mathrm{EU} \rightarrow \mathrm{BMI}$ & & & & & $.12^{*}$ & 1.90 & .01 & 1.48 \\
\hline & $\mathrm{PAC} * \mathrm{EU} \rightarrow \mathrm{SF}$ & & & & & .07 & .99 & .01 & 1.49 \\
\hline & $\mathrm{RAC} * \mathrm{EU} \rightarrow \mathrm{SF}$ & & & & & -.03 & .41 & .00 & 1.48 \\
\hline \multirow{10}{*}{$\begin{array}{l}\vdots \\
\vdots \\
\vdots \\
0\end{array}$} & $\mathrm{FA} \rightarrow \mathrm{BMI}$ & -.04 & .61 & .00 & 1.13 & -.04 & .75 & .00 & 1.13 \\
\hline & $\mathrm{CH} \rightarrow \mathrm{BMI}$ & $-.10 *$ & 1.77 & .01 & 1.02 & $-.11 *$ & 1.95 & .02 & 1.03 \\
\hline & $\mathrm{EU} \rightarrow \mathrm{BMI}$ & $.29 * * *$ & 5.35 & .10 & 1.07 & $.29 * * *$ & 5.34 & .10 & 1.07 \\
\hline & $\mathrm{FO} \rightarrow \mathrm{BMI}$ & .02 & .40 & .00 & 1.13 & .03 & .51 & .00 & 1.13 \\
\hline & $\mathrm{FS} \rightarrow \mathrm{BMI}$ & $.19 * * *$ & 3.18 & .04 & 1.13 & $.20 * * *$ & 3.34 & .05 & 1.15 \\
\hline & $\mathrm{FA} \rightarrow \mathrm{SF}$ & -.04 & .83 & .00 & 1.13 & -.04 & .72 & .00 & 1.13 \\
\hline & $\mathrm{CH} \rightarrow \mathrm{SF}$ & .03 & .49 & .00 & 1.02 & .03 & .54 & .00 & 1.02 \\
\hline & $\mathrm{EU} \rightarrow \mathrm{SF}$ & -.04 & .76 & .00 & 1.07 & -.04 & .78 & .00 & 1.07 \\
\hline & $\mathrm{FO} \rightarrow \mathrm{SF}$ & $-.11 * *$ & 2.01 & .02 & 1.11 & $-.11 * *$ & 2.03 & .02 & 1.11 \\
\hline & $\mathrm{FS} \rightarrow \mathrm{SF}$ & .01 & .10 & .00 & 1.13 & .00 & .05 & .00 & 1.15 \\
\hline \multirow{6}{*}{ 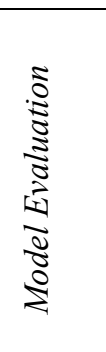 } & $\mathrm{R}^{2} \mathrm{BMI}$ & & .21 & & & & .22 & & \\
\hline & $\mathrm{R}^{2}$ adjusted BMI & & .19 & & & & .20 & & \\
\hline & $\mathrm{R}^{2} \mathrm{SF}$ & & .35 & & & & .36 & & \\
\hline & $\mathrm{R}^{2}$ adjusted $\mathrm{SF}$ & & .34 & & & & .33 & & \\
\hline & $\mathrm{R}^{2} \mathrm{PAC}$ & & .30 & & & & .30 & & \\
\hline & $\mathrm{R}^{2}$ adjusted PAC & & .30 & & & & .30 & & \\
\hline
\end{tabular}

Note: Significant at ${ }^{* * *} \mathrm{p}<.01,{ }^{* *} \mathrm{p}<.05,{ }^{*} \mathrm{p}<.1 ; \mathrm{BMI}=$ Business Model Innovation; $\mathrm{SF}=$ Strategic Flexibility; PAC $=$ Potential Absorptive Capacity; RAC $=$ Potential Absorptive Capacity; EU = Environmental Uncertainty; FA = Firm Age; $\mathrm{CH}=$ Company Handover; FO = Family Ownership; FS = Firm Size; VIF = Variance Inflation Factor

Table 6: Results (continued) 


\begin{tabular}{lcc}
\hline Latent Variables & $\mathrm{Q}^{2}(\mathrm{OD}=7)$ & $\mathrm{q}^{2}$ Effect Sizes \\
\hline Business Model Innovation & .10 & \\
Model Without Potential Absorptive Capacity & .08 & .02 \\
Model Without Realized Absorptive Capacity & .09 & .00 \\
Model Without Strategic Flexibility & .10 & -.01 \\
Model Without Firm Age & .10 & .00 \\
Model Without Company Handover & .08 & .02 \\
Model Without Environmental Uncertainty & .05 & .05 \\
Model Without Family Ownership & .10 & .00 \\
Model Without Firm Size & .08 & .02 \\
\hline
\end{tabular}

Table 7: $\mathrm{q}^{2}$ Effect Sizes for BMI

\begin{tabular}{lcc}
\hline Latent Variables & $\mathrm{Q}^{2}(\mathrm{OD}=$ & $\mathrm{q}^{2}$ Effect Sizes \\
& $7)$ & \\
\hline Strategic Flexibility & .23 & \\
Model Without Potential Absorptive Capacity & .20 & .04 \\
Model Without Realized Absorptive Capacity & .17 & .08 \\
Model Without Firm Age & .23 & .00 \\
Model Without Company Handover & .23 & .00 \\
Model Without Environmental Uncertainty & .23 & .00 \\
Model Without Family Ownership & .22 & .01 \\
Model Without Firm Size & .23 & .00 \\
\hline
\end{tabular}

Table 8: $q^{2}$ Effect Sizes for Strategic Flexibility 